\title{
Challenges and an Implementation Framework for Sustainable Municipal Organic Waste Management Using Biogas Technology in Emerging Asian Countries
}

\author{
Andante Hadi Pandyaswargo ${ }^{1, *(\mathbb{D})}$, Premakumara Jagath Dickella Gamaralalage ${ }^{2}$, Chen Liu ${ }^{2}$, \\ Michael Knaus ${ }^{3}{ }^{(D)}$, Hiroshi Onoda ${ }^{1}$, Faezeh Mahichi ${ }^{4}$ and Yanghui Guo ${ }^{1}$ \\ 1 Graduate School of Environment and Energy Engineering, Waseda University, Tokyo 169-8555, Japan; \\ onoda@waseda.jp (H.O.); kaku18@akane.waseda.jp (Y.G.) \\ 2 Institute for Global Environmental Strategies, Hayama 240-0115, Japan; premakumara@iges.or.jp (P.J.D.G.); \\ c-liu@iges.or.jp (C.L.) \\ 3 The Institute for Applied Material Flow Management, Birkenfeld 55768, Germany; \\ m.knaus@umwelt-campus.de \\ 4 Ritsumeikan Asia Pacific University, Beppu 874-8577, Japan; fmahichi@apu.ac.jp \\ * Correspondence: andante.hadi@aoni.waseda.jp
}

Received: 4 September 2019; Accepted: 8 November 2019; Published: 11 November 2019

\begin{abstract}
Due to its ability to recover both material and energy from organic waste, biogas technology is considered one of the best technology for treating organic waste. While in many emerging Asian countries more than $50 \%$ of municipal waste is organic waste, the amount of organic waste treated with biogas technology remains very limited. This study identified key challenges faced by practitioners in sustaining biogas plants from literature and interviewed a number of sustainably operating biogas plant managers and, based on the findings, developed an implementation framework to help decision makers and practitioners in planning a sustainable municipal organic waste biogas plant facility.
\end{abstract}

Keywords: anaerobic digestion; biogas; developing countries; organic waste; municipal solid waste; energy recovery; material recovery

\section{Introduction}

Biogas or the anaerobic digestion (AD) technology is one of the oldest forms of renewable energy (RE) [1]. The first evidence of the use of this technology was found in ancient literature from various parts of the globe [2]. Biogas technology is also known to be one of the most appropriate alternatives to treat organic waste due to its ability to recover both material (for example, the solid part as soil conditioner or organic fertilizer, the liquid part as fertigation water or liquid fertilizer) and energy (for example the gas can be upgraded to natural gas quality and used as vehicle fuel, or converted into electricity) from waste. The multifaceted nature of this approach renders it a highly ranked method within the waste management hierarchy [3] and an excellent tool for the realization of circular economy [4-7]. On the other hand, organic waste from municipalities has great potential to be used as a substrate for biogas plants and may impose environmental burdens when not properly handled. In low- and middle-income countries, the biggest fraction of municipal waste is the organic waste [8], and the large majority of Asia Pacific countries are of the middle-income category [9]. This study focuses on the emerging (lower-middle and upper-middle) Asian region because there is potential to use biogas plant technology to increase energy supplies generated from organic municipal waste and to respond to mounting waste management challenges emerging from the region's population growth. Despite its long history, technological viability, and environmental benefits, biogas technology for municipal solid waste treatment is not applied to as high a degree in emerging Asia as it is in European 
countries. Of the estimated $42 \mathrm{Gm}^{3}$ of biogas produced worldwide in 2008 , only $15 \mathrm{Gm}^{3}$ was produced in non-Organization for Economic Co-operation and Development (non-OECD) countries and $98.4 \%$ was generated in China [10,11]. In Europe, led by Germany, there are a total of 17,240 AD plants with an 8293 MWel capacity [12]. The annual capacity growth of AD in Europe is even higher than the growth of the number of plants [12], indicating that more biogas plants of greater capacity are being built each year. In the emerging Asian region, the technology is more commonly applied at the household scale in rural areas using animal manure $[10,13,14]$ and often as a result of mass development programs supported by international organizations and government projects [15-17]. There are various factors that may hinder the sustainability of biogas plants using municipal waste processing at larger scales. This study hypothesizes that multiple conditions must be met and that various strategies must be applied at the planning stage to avoid sustainability problems along the lifetime of a biogas plant. In addition to technical solutions and financial aids, considerations in the social sectors must also be addressed. Studies have shown that poorly allocated project grants can lead to a poor sense of ownership [18], [19]. Even when human resources are available with the required capacity, this does not necessarily correlate with a willingness to sustain a project [20]. To be sustainable, a project must be addressed by considering multiple sustainability factors. A number of review studies on AD have been performed with different focuses. For example, some studies have covered technical issues [21,22] and issues of the domestic scale [14,23-25], while others have presented regional reviews for the European region [26-28] and cross-sectional reviews of the sustainability of renewable energy practices adopted in developing countries [19]. Our study reviews the challenges faced by biogas plant practitioners and, based on this, develops a framework of factors required to sustain a municipal organic waste biogas plant in emerging Asia.

\section{Review Methods}

We employed two methods in this study; first, we reviewed previous scientific studies published in journal articles, books, and reports to identify the challenges experienced by existing biogas plants and from research worldwide. Second, we interviewed a number of sustainably operating biogas plant managers in five Asian countries (China, Japan, The Philippines, Indonesia, and India) to understand how they have overcome various challenges and how they maintain the sustainability of their plants.

Among the literature, individual studies have focused on specific challenges in reference to various contexts. A qualitative synthesis can facilitate the accumulation of findings from individual studies [29,30]. In this study, we reviewed journal articles collected from the Science Direct and Web of Science databases. Additionally, although not all are quite recent, books and guidelines on the implementation of biogas technology were also included for their high relevancy [31-35]. For journal articles, to minimize the inclusion of outdated technical challenges, our search was limited to those published after 2010. The terms "anaerobic digestion" and "biogas" were assumed to be interchangeable and thus we used the following keywords in searching through the literature: "anaerobic digestion" OR "biogas", "anaerobic digestion" OR "biogas" AND "municipal waste", "anaerobic digestion" OR "biogas" AND "municipal waste" and "developing Asian countries". Findings were further manually refined to include only relevant publications, resulting in 127 journal articles. To offer a broad account of the various characteristics of biogas plants discussed in the selected studies, publications were categorized based on the following features: the location of the study, the substrate used in the biogas plant, the capacity of the biogas plant, and the use of outputs.

Based on our literature review, we summarized key findings into technical, financial, and social challenges. Through interviews held with the project managers from five different countries, we identified how these challenges could be addressed. To summarize, we constructed a framework of elements necessary to consider in order to sustainably implement municipal solid waste biogas plant in the emerging Asian context. 


\section{Review of Biogas Plant Challenges Identified from Previous Research}

Previous studies discussing the technical, financial and social challenges of biogas technologies have been conducted in various locations globally and have used various substrates. The features of a biogas plant discussed in previous studies are summarized in Section 3.1., key challenges categorized into common groups and sustainable solutions in response to such challenges are discussed in Section 3.2.

\subsection{Biogas Plant Project Features from the Collected Literature}

Biogas plant projects discussed in the literature have different features and characteristics. We categorized these features based on the following parameters: locations, substrates, capacities, and the use of outputs (Table 1). Location wise, we categorized projects conducted in emerging and developed countries. "Emerging countries" in this case are defined as low- and middle-income countries, while "developed countries" are defined as high-income countries based on the World Bank's country classification by income [36]. Based on the types of substrates involved, projects observed in the literature commonly used the organic fraction of municipal solid waste, animal manure, agricultural residue, a combination of these (co-digestion), or various combinations using sewage sludge and industrial waste. Capacity wise, while one study provides a scale for categorizing biogas plant capacities (low $=<1000 \mathrm{~m}^{3}$, moderate $=1000-10,000 \mathrm{~m}^{3}$, and high $=>10,000 \mathrm{~m}^{3}$ ) [26], no common definition of what is considered low, moderate, and high is given in the rest of the reviewed studies. In this study, we categorized a household scale biogas plant as small and anything larger as moderate or large, with medium- and large-scale biogas plants defined as those operating at the community and city levels, respectively. Biogas outputs of smaller scale biogas plants are commonly used for cooking fuel and lighting in rural areas, though one study found a featured community level biogas plant to supply cooking fuel for roughly 1000 households in Thailand [37]. Heat and electricity are other common uses of biogas across different capacities while only large-scale biogas plants appear to be feasible for biogas upgrading to natural gas quality and for fuel generation (e.g., for public transportation).

Table 1. Summary of biogas project features presented in the reviewed literature.

\begin{tabular}{|c|c|c|}
\hline Features of the Biogas Plant Projects & Reference Number(s) & Key Finding(s) \\
\hline \multicolumn{3}{|l|}{ Location } \\
\hline Emerging country ${ }^{\mathrm{a}}$ & $([37-40])$ & \\
\hline Developed country ${ }^{b}$ & $([41-44])$ & \\
\hline Substrates & & \multirow{5}{*}{$\begin{array}{l}\text { Co-digestion strategy has been } \\
\text { implemented to address various technical } \\
\text { challenges including to secure feedstock } \\
\text { volume to satisfy the plant capacity and to } \\
\text { stabilize carbon/nitrogen ratio. }\end{array}$} \\
\hline Municipal solid waste & $([38,45-47])$ & \\
\hline Animal manure & $([39,48-50])$ & \\
\hline Agricultural residue & $([51-54])$ & \\
\hline Co-digestion ${ }^{c}$ & $([23,41,55,56])$ & \\
\hline Capacity & & \multirow{3}{*}{$\begin{array}{l}\text { Small-scale plants using animal manure } \\
\text { are commonly found in the rural area. }\end{array}$} \\
\hline Household scale (small) & $([25,40,57,58])$ & \\
\hline Community or city scale (medium to large) & $([37,39,42,46])$ & \\
\hline Use of Outputs & & \multirow{4}{*}{$\begin{array}{l}\text { Biogas upgraded for transportation fuel } \\
\text { was found most feasible at larger-scale } \\
\text { plants (several tens of thousand tons per } \\
\text { day capacity). }\end{array}$} \\
\hline Cooking fuel and Lighting & $([37,40,59,60])$ & \\
\hline Heat and electricity & $([43,50,61,62])$ & \\
\hline Gas (upgraded to natural gas quality) & $([26,63,64])$ & \\
\hline
\end{tabular}

\subsection{Key Challenges of Biogas Plants Using Municipal Organic Waste}

The identified challenges were synthesized from our literature review and categorized into three groups: technical, financial, and social factors. 


\subsubsection{Technical Challenges}

Key findings concerning technical challenges facing biogas plants are summarized in Table 2 . The amount of biogas produced in a biogas plant is closely related to the purity of substrates. Pre-sorted organic waste is technically purer than when waste is mechanically sorted post-collection. In places where waste segregation is not practiced at an impeccable manner, Mechanical Biological Treatment (MBT) facilities may be used to improve organic waste purity [65]. Another important point related to substrate conditions concerns the stability of supplies. For some agricultural practices applied to seasonal harvests, the substrate generated from agricultural residue may undergo fluctuations and affect the performance of a biogas plant. This challenge, however, can be addressed via co-digestion, which can not only improve substrate supply stability levels, but which can also correct the carbon-to-nitrogen $(\mathrm{C} / \mathrm{N})$ ratio to the desired level [35]. In an urban setting, substrate supply fluctuations are mostly caused by infrastructural problems rather than production problems. Therefore, it is necessary to ensure reliable transportation and infrastructure to improve supply stability levels [24].

Table 2. Summary of technical challenges.

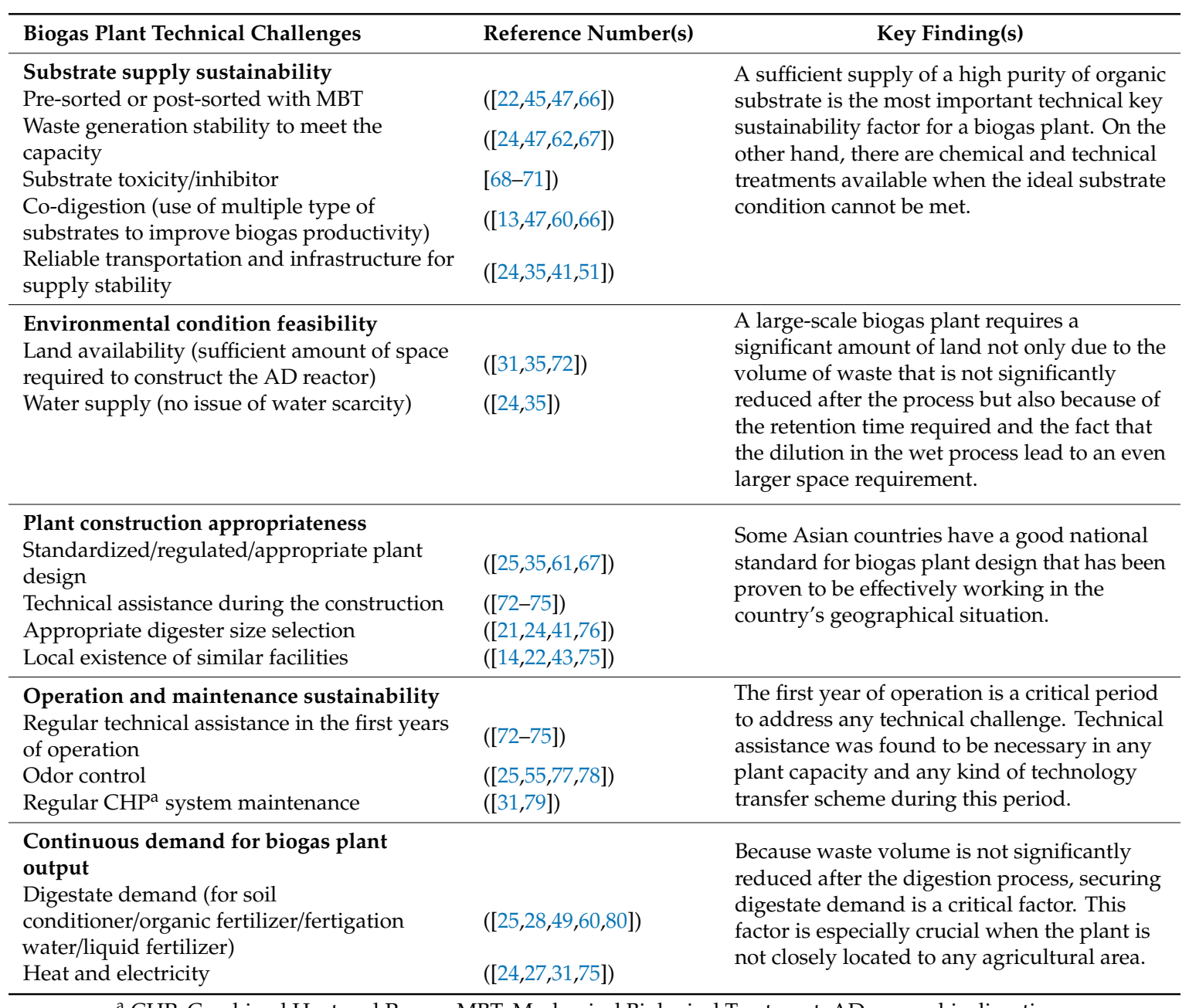

a CHP: Combined Heat and Power; MBT: Mechanical Biological Treatment; AD: anaerobic digestion.

There is a critical technical issue that has hindered the use of municipal waste in a biogas plant; an AD process is sensitive to toxicants and there is a wide range of compounds that may be found in the municipal waste composition that could upset the process. Chen et al. [71] have summarized that the toxicants that may inhibit an AD process in their review paper. What these toxicants are and what effects they cause to AD process is quoted from their paper as follows: "Inhibitory toxic compounds include organics, ammonia, sulfide, heavy metals, and the emerging nanomaterials, and are often 
present in the processing of wastes from agricultural and industrial operations such as molasses fermentation, petroleum refining and the tanning industries. These toxic compounds principally obstruct the activities of the sensitive obligate hydrogen producing acetogens and methanogenic portions of the digester population, as well as cause retarded methane formation, a decrease in the methane content of biogas, or can even cause complete failure of methanogenesis." While the toxicants and their effects are widely researched [68-70,81-86], the uncertainty of which compounds may exist in the feedstock and the widely varied effects led operators to respond to the challenge only after the inhibition (by detoxification) but not prior (by stopping the toxicants from entering the digester) [71]. Chen et al. suggested that plant operators ensure robust monitoring of toxicant levels and rapid response mechanisms to overcome this problem until research advanced to identifying the pre-measurement of toxicity strategies before the waste is introduced into the digester [71]. The next technical challenge involves securing environmental conditions required for biogas plant implementation. A biogas reactor, depending on its capacity and on whether it is positioned below or aboveground, can take up a significant amount of space. Therefore, a sufficient amount of space is required to construct a biogas reactor. Moreover, it must be positioned in a suitable location to guarantee soil stability (not on the cliff, etc.) [35] and at a certain distance from the residential area to prevent odor issues from arising. Both wet and dry biogasification processes involve using a significant amount of water to maintain supporting bacteria [31]. Therefore, the reliability of water supplies is a crucial technical environmental factor $[24,35]$ indispensable to guaranteeing the sustainability of a biogas plant.

Appropriate technologies are not only those that are suited to the socioeconomic conditions of the local community but must also perform effectively in the environments in which they are operated. While this criterion is complex, through experience and continuous improvement, it can be achieved. Once an ideal design is developed, it should be documented as a standard guideline so that future implementers can refer to it. This is what the Netherlands Development Organization (SNV) has carried out through its various mass projects in developing countries [74]. One case study conducted in Indonesia developed national design standards for home biogas referred to as Standard Nasional Indonesia (SNI) No. 7826 in 2012. By ensuring that reactors are built with appropriate plant design and expertise in engineering construction, risks of technical failures such as reactor leakage can be minimized. A plant should then be monitored regularly for maintenance and troubleshooting should technical problems arise. Another important parameter related to an effective biogas plant relates to the selection of appropriate digester sizes and to the existence of similar facilities in the given area. The existence of similar facilities can not only verify that technologies used could work in a given environment and under certain socio-economic conditions but can also facilitate communal efforts (e.g., the sharing of mature slurry to support a new biogas plant could be made possible at the local level) [35]. Furthermore, odor control and regular Combined Heat and Power (CHP) systems, when present, should be maintained regularly for effective operation. A foul odor that is more intense than usual can be an indicator that something has gone wrong within a reactor (resulting in poor gas quality) and should be inspected accordingly [35].

At the end stream of a biogas plant, digestate is recovered as well as energy of various forms. The volume of digestate is not significantly different, or usually more than the volume of substrates due to additional substances such as water [87-89]. Demand for digestate is, therefore, a fundamental factor that shapes the sustainability of a biogas plant. The presence of a farm that can make use of digestate/bio-slurry as a soil conditioner or organic fertilizer and as fertigation water or liquid fertilizer can relieve a plant of considerable financial burdens [59]. There should also be demand for heat and electricity either to be used by the plant itself or for the community around it [16]. Similar to other renewable energy plants, a clear and reliable mechanism for electricity or gas delivery to the main grid can ensure the sustainability $[90,91]$ of larger biogas plants. 


\subsubsection{Financial Challenges}

Key financial challenges were synthesized from the literature reviews and are summarized in Table 3. The financial challenge most frequently mentioned in the literature concerns the securing of initial investment funds. Biogas plant projects of various scales rely on external support in the form of government subsidies and soft loans [73,75]. Financial assistance from private investments with public-private alliance (PPA) or public-private partnership (PPP) mechanisms may also be required. For larger biogas plants, project technology transfer mechanisms such as design-build-operate (DBO) or build-operate-transfer (BOT) schemes may render the private sector more confident in investing in a project.

Table 3. Summary of financial challenges.

\begin{tabular}{|c|c|c|}
\hline Biogas Plant Financial Challenges & Reference Number(s) & Key Finding(s) \\
\hline $\begin{array}{l}\text { Investment support } \\
\text { Support for Initial investment } \\
\text { (donor/subsidies) } \\
\text { Private investment } \mathrm{PPA}^{\mathrm{a}} / \mathrm{PPP}^{\mathrm{b}} \\
\text { Project technology transfer scheme for large } \\
\text { scale AD (e.g., DBO } \text { BOOT }^{\mathrm{d}} \text { ) }\end{array}$ & $\begin{array}{l}([19,34,55,73,75,92]) \\
([18,24,77,78]) \\
([8,33,77])\end{array}$ & $\begin{array}{l}\text { Investment cost is one of the biggest } \\
\text { hurdles in starting a biogas plant, but as } \\
\text { energy from biogas considered as a } \\
\text { renewable energy, there are various } \\
\text { assistance available from the government, } \\
\text { NGO }^{e} \text {, banks, and the private sectors. }\end{array}$ \\
\hline $\begin{array}{l}\text { Financial support mechanism during } \\
\text { operation } \\
\text { Guarantee of ambitious FIT }{ }^{\mathrm{f}} \text { income/green } \\
\text { tariffs } \\
\text { Tax waving } \\
\text { Fertilizer pricing system } \\
\text { Guarantee of gate fee/tipping fee }\end{array}$ & $\begin{array}{l}([22,28,93,94]) \\
([33,34,74,95]) \\
([24,25,69]) \\
([24,44,46,50])\end{array}$ & $\begin{array}{l}\text { Green tariff mechanisms and income from } \\
\text { selling fertilizer often become the bottle } \\
\text { neck of financial sustainability of a biogas } \\
\text { plant. The effectiveness often depends on } \\
\text { how stringent the government is in } \\
\text { implementing such supports. }\end{array}$ \\
\hline $\begin{array}{l}\text { Stable market demand to sell output, and } \\
\text { competitive pricing } \\
\text { Heat and electricity market } \\
\text { Digestate market }\end{array}$ & $\begin{array}{l}([31,42,44,50]) \\
([28,41,59,69])\end{array}$ & $\begin{array}{l}\text { While heat and electricity could be used } \\
\text { internally for the plant operation and } \\
\text { management, digestate market is often } \\
\text { external and require additional } \\
\text { investment to improve its quality to be } \\
\text { acceptable by the market demand. }\end{array}$ \\
\hline
\end{tabular}

${ }^{a}$ PPA: public-private alliance; ${ }^{b}$ PPP: public-private partnership; ${ }^{c}$ DBO: design-build-operate; ${ }^{d}$ BOT: build-operate-transfer; ${ }^{\mathrm{e}}$ NGO: Non-Government Organization; ${ }^{\mathrm{f}}$ FIT: Feed-in tariff.

Once a biogas plant is established, the following income sources can help ensure the plant's financial sustainability: (1) feed-in tariffs (FITs), (2) tax waving, (3) income generated from selling substrates, and (4) tipping/gate fees. An ambitious and clear FIT or other kinds of green tariffs may provide continuous financial income especially when such tariffs are guaranteed through banks or other formal financial institutions. While a larger percentage of energy generated is technically used for heat, FIT income from electricity generation remains an attractive incentive. Tax waving represents another interesting incentive in the case of renewable energy in general and for a biogas plant especially it becomes a significant financial attraction with an increase in plant size. Fertilizer pricing and gate fees in many cases are strong determinants that directly affect the overall financial health of a biogas plant. Therefore, these two features should be guaranteed through laws and regulations with stringent implementation by governments.

Finally, without stable demand, a surplus of energy and digestate will become waste, and unusable waste incurs costs. Heat, electricity and digestate should be in constant demand for biogas plants to supply.

\subsubsection{Social Challenges}

The main social challenges identified were synthesized from the literature review and are summarized in Table 4. Social dynamics are very different from place to place because they are affected by numerous factors that are not always tangible and that do not always have direct effects. From the reviewed literature, operators' levels of commitment to sustaining technologies represent the most 
influential bottleneck. When there is a lack of ownership, technologies may be abandoned with the most minor technical challenge. A sense of ownership and a willingness to sustain systems are not even necessarily related to financial support or technical capabilities [20,35], as sometimes financial grants that are not carefully designed are taken for granted, causing the operator to lose interest as various challenges arise. Such challenges may be better mitigated when there is collaboration with various stakeholders. For example, according to an Indonesian case study [35], one operator with good leadership skills collaborated with technicians and university staff to address technical issues.

Table 4. Summary of social challenges.

\begin{tabular}{|c|c|c|}
\hline Biogas Plant Social Challenges & Reference Number(s) & Key Finding(s) \\
\hline $\begin{array}{l}\text { Operator commitment } \\
\text { Continuous participation in operation/sense } \\
\text { of ownership/willingness to sustain }\end{array}$ & $([18,20,35,75,96])$ & $\begin{array}{l}\text { Operator commitment is what holds } \\
\text { things together when challenges arise. In } \\
\text { addition to knowledge and capacity, it } \\
\text { also requires soft skills such as leadership, } \\
\text { curiosity, networking, and overall strong } \\
\text { willingness to sustain the technology. }\end{array}$ \\
\hline $\begin{array}{l}\text { Existence of supporting government } \\
\text { regulations } \\
\text { National MSW laws and enforcement } \\
\text { Fertilizer control system } \\
\text { Related ministries cooperation } \\
\text { Clear PPA }{ }^{\mathrm{a}} \mathrm{PPP}^{\mathrm{b}} \text { regulations }\end{array}$ & $\begin{array}{l}([49,60,77,93]) \\
([31,97-99]) \\
([8,33,49,100]) \\
([18,24,77,78])\end{array}$ & $\begin{array}{l}\text { Government regulations are strongly } \\
\text { related to other sustainability factors } \\
\text { including the previously mentioned } \\
\text { technical and financial factors. }\end{array}$ \\
\hline $\begin{array}{l}\text { Other social factors } \\
\text { Inclusion of local labor workers and } \\
\text { technicians } \\
\text { Collaboration with various stakeholders } \\
\text { Leadership (leader's attitude towards clean } \\
\text { energy) } \\
\text { Guarantee for safety } \\
\text { Ease of operation } \\
\text { Aesthetic consideration } \\
\text { Ethical barriers or socio-cultural taboos }\end{array}$ & $\begin{array}{l}([8,18,19,24,34]) \\
([35,74,75,77]) \\
([8,18,34,77]) \\
([33,35,43,101]) \\
([18,25,35,96]) \\
([18,34,35,102]) \\
([8,18,30,34])\end{array}$ & $\begin{array}{l}\text { While social factors might be seen as } \\
\text { something "soft" and "abstract", they } \\
\text { could be the determining factor of } \\
\text { whether or not the project will kick-off } \\
\text { and sustain. Since social factors would } \\
\text { vary from place to place, a thorough social } \\
\text { assessment must be conducted prior to } \\
\text { implementation of the project. }\end{array}$ \\
\hline
\end{tabular}

MSW: Municipal Solid Waste.

Governments can support biogas technology use by forming regulations that favor the sustainability of biogas plants [103]. The most basic regulations that must be enforced are national municipal solid waste laws [93]. When waste separation regulations are enforced and source separation can take place, the purity of organic waste can improve [93], improving biogas plant performance. In some areas, there are negative perceptions of substrate use for agricultural purposes especially due to fears of high levels of heavy metals [104] and other hazardous elements in the substrate. When the fertilizer control system adopted is discussed, such fears can be addressed, leading to more acceptance of the use of substrates from biogas plants as soil conditioners. Cooperation among ministries can also improve the social sustainability of biogas plants [72]. For example, ministries of education can provide educational resources on the importance of proper waste management for primary education curricula. Ministries of health can also educate the public on the health effects of landfills and of burning municipal waste. Ministries of energy and the environment must acknowledge and enforce adopted technologies as tools for conserving resources, reducing pollution, and providing renewable energy.

Other social challenges identified from the literature include the following: the use of local labor, guaranteeing safety, ease of operations, aesthetic considerations, and consideration of ethical barriers or social taboos. These challenges related to other challenges. For example, the involvement of local labor results in more accessible technical assistance and in more affordable services. This strategy also lessens the financial burdens of plant maintenance. Guaranteeing safety is always a central concern when new technologies are implemented. By equipping operators with technical maintenance capacities, such concerns can be addressed, and the presence of a similar facility in a given area can improve the acceptability of adopted technologies. As not all operators are physically fit, the ease of operations 
must also be considered. For small-scale biogas plants, inlets are sometimes raised aboveground, making it difficult for an elderly operator to feed the substrate.

\section{Biogas Plant Sustainability Factors Identified from Interviews with Plant Managers}

To collect diverse ideas about the sustainability factors of biogas plants, we interviewed six biogas plant managers from five different countries who operate different biogas project with different features. The first interviewee was a biogas project manager from China. Our second and third interviewee was from two biogas plants in Japan (one using kitchen waste from the residential area and the other one using supermarket and convenience store food waste). Then, our fourth, fifth, and sixth interviewee were from the emerging Asian region. We interviewed biogas plant managers from Indonesia (mass implementation, small scale, animal manure-based), from the Philippines (large scale, animal manure-based), and India (two ward-scale plants, one plant using fruit and vegetable market waste and the other one using municipal solid waste). The interview questions were structured as follows: (1) Project background (geographical location of the plant, key partners or implementation and the starting year), (2) Basic explanation of the operation and monitoring of the biogas plant project (size, substrate, operation, digestate use, and costs), and (3) Lessons learned from the biogas plant project (key factors for success or failures/sustainability factors) (Figure 1). The summary of the interviewed case studies is presented in Table 5, and the details are elaborated in Sections 4.1-4.5.

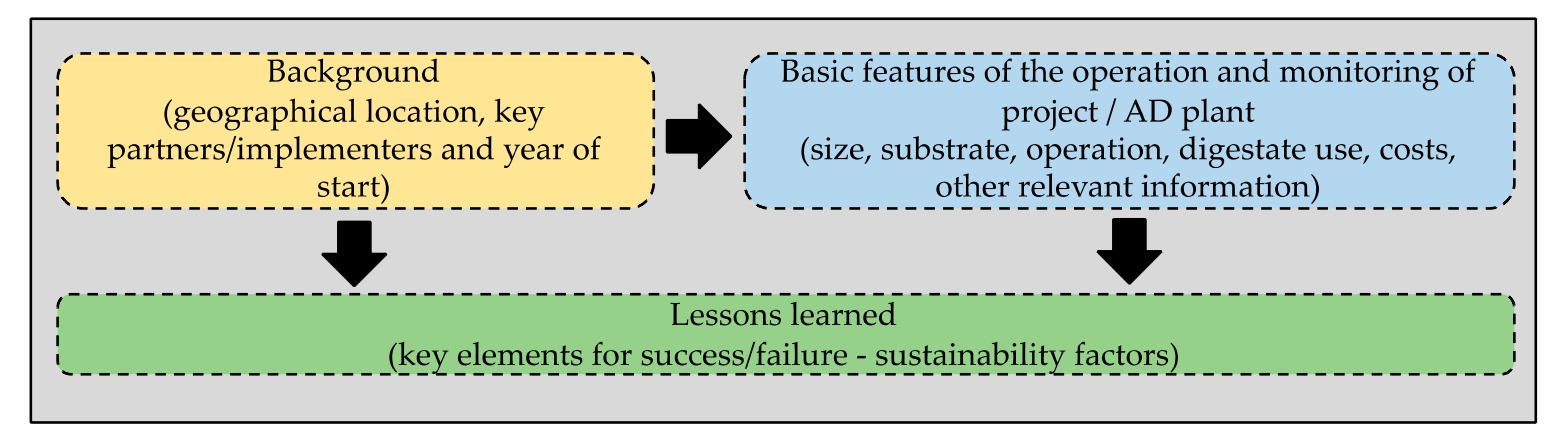

Figure 1. Semi-structured interview question flow. 
Table 5. Summary of the interviewed case studies.

\begin{tabular}{|c|c|c|c|}
\hline Case Study No. & Background & Basic Features of Operation and Maintenance & Lessons Learned/Sustainability Factors \\
\hline 1 & $\begin{array}{l}\text { - Geographical location: China (Zhejiang } \\
\text { Province, Shaoxing City, Keqiao) } \\
\text { - } \quad \text { Key partners/implementers: Local } \\
\text { government and private sector } \\
\text { - } \quad \text { Year of start: } 2018\end{array}$ & $\begin{array}{l}\text { Capacity: Medium-large (547 Ton Per Day } \\
\text { (TPD)) } \\
\text { - Substrate: } 370 \text { TPD household food waste; } 177 \\
\text { TPD restaurant kitchen waste } \\
\text { - Operation: eco-mechanical biological } \\
\text { technology (EMBT) } \\
\text { - Digestate use: The solids for soil conditioner } \\
\text { and the liquid is treated in the nearby sewage } \\
\text { treatment plant } \\
\text { - } \quad \text { Energy generation: } 2700 \mathrm{kWh}-\mathrm{el} / \text { day } \\
\text { - Costs: Investment cost approx. } 270 \text { million } \\
\text { CNY (or } 32 \text { million USD) under } \\
\text { PPP mechanism. } \\
\text { Other relevant information: De-oil (oil } \\
\text { extraction step in the pre-treatment process). }\end{array}$ & 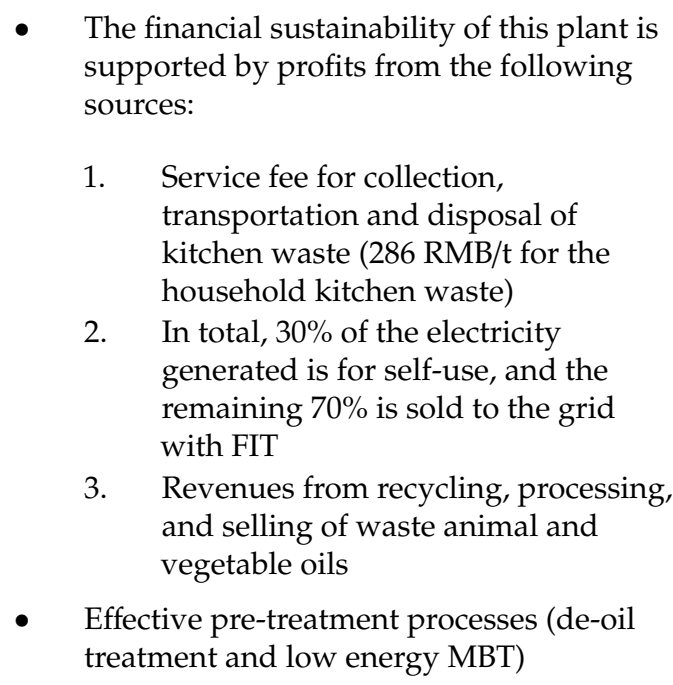 \\
\hline 2 & $\begin{array}{l}\text { - Geographical location: Japan (Oki } \\
\text { Town, Fukuoka prefecture) } \\
\text { - } \quad \text { Key partners/implementers: } \\
\text { Local government } \\
\text { - Year of start: } 2006\end{array}$ & $\begin{array}{l}\text { - } \quad \text { Capacity: Medium-large (41 TPD) } \\
\text { - } \quad \text { Substrate: 3.8 TPD kitchen waste } 7 \text { TPD } \\
\text { human waste; 30.6 TPD septic tank sludge. } \\
\text { Operation: Mesophilic temperature fermenter } \\
\text { (37 degrees Celsius, } 22 \text { days) } \\
\text { - } \quad \text { Digestate use: Bio-slurry for agriculture } \\
\text { - } \quad \text { Cosergy generation: } 697 \mathrm{kWh}-\mathrm{el} / \text { day } \\
\text { by incineration } \\
\text { Other relevant information: Strong } \\
\text { community participation }\end{array}$ & $\begin{array}{ll}\text { - } & \text { Good leadership practice } \\
\text { - } & \text { Local inclusiveness and good resource } \\
\text { - } & \text { Good separation and collection system } \\
\text { - } & \text { Development of liquid manure as } \\
\text { a commodity } \\
\text { - } \quad \begin{array}{l}\text { Development of market for agricultural } \\
\text { products grown using liquid manure }\end{array} \\
\text { - } \quad \text { Integrated technology transition with } \\
\text { - } \quad \text { Crocial transition } \\
\text { - } \quad \text { and domestic waste treatment } \\
\text { - } \quad \text { and capacity building } \\
\text { Stable and high-quality waste input }\end{array}$ \\
\hline
\end{tabular}


Table 5. Cont.

\begin{tabular}{|c|c|c|c|}
\hline Case Study No. & Background & Basic Features of Operation and Maintenance & Lessons Learned/Sustainability Factors \\
\hline 3 & $\begin{array}{l}\text { Geographical location: Japan (Ota } \\
\text { ward, Tokyo city) } \\
\text { - Key partners/implemneters: Private } \\
\text { sector and municipal government } \\
\text { - Year of start: } 2003\end{array}$ & $\begin{array}{l}\text { - } \quad \text { Capacity: Medium-large (130 TPD) } \\
\text { - } \text { Substrate: } 130 \text { TPD supermarket and } \\
\text { - } \quad \text { Operation: } \\
\text { - } \quad \text { Digestate use: incinerated } \\
\text { - } \quad \text { Energy generation: } 26,880 \mathrm{kWh}-\mathrm{el} / \text { day and } \\
\text { - } 2400 \mathrm{~m} 3 \text { city gas/day } \\
\text { Costs: investment cost supported partially by } \\
\text { - } \quad \text { Othe government } \\
\text { used to supply approx. } 2000 \text { households }\end{array}$ & $\begin{array}{l}\text { - } \quad \text { Government support for the } \\
\text { investment cost } \\
\text { - Warrant of income from FIT, gate fee from } \\
\text { companies (supermarkets, convenient } \\
\text { store, other industries needing to dispose } \\
\text { their organic waste) } \\
\text { - } \quad \text { High demand for city gas } \\
\text { - Strategic location (related to good } \\
\text { proximity to high supply, demand, and } \\
\text { incineration plant) } \\
\text { - Strong government regulation about } \\
\text { waste handling } \\
\text { Use of MBT technology effective for } \\
\text { unpacking plastic food packages (wraps, } \\
\text { containers, etc.) }\end{array}$ \\
\hline 4 & $\begin{array}{l}\text { - Geographical location: Indonesia } \\
\text { (14,173 AD plants in nine provinces } \\
\text { by 2018) } \\
\text { - Key partners/implementers: Non-profit } \\
\text { international organization, government, } \\
\text { non-profit local organization } \\
\text { - Year of start: } 2009\end{array}$ & $\begin{array}{ll}\text { - } & \text { Capacity: Small size (household scale) } \\
\text { - } & \text { Substrate: Animal manure, small-scale } \\
\text { - } & \text { Opod industry } \\
\text { - } & \text { Digeration: Fixed dome digester } \\
\text { - } & \text { Energy generation: biogas for } \\
& \text { household lighting } \\
\text { - } & \text { Costs: Partial subsidy for investment cost } \\
\text { - Other relevant information: Reward system for } \\
\text { high performance }\end{array}$ & $\begin{array}{l}\text { - } \quad \text { High substrate purity (often homogenous) } \\
\text { The project takes place in mostly in areas } \\
\text { where there is no cheaper alternative of } \\
\text { electrification or cooking gas. } \\
\text { Biogas operators are people who produce } \\
\text { enough amount of biogas to meet the } \\
\text { capacity (farmers or the small-scale food } \\
\text { industry). } \\
\text { Technical assistance for trouble-shooting is } \\
\text { available from the dissemination project } \\
\text { Small-scale, fixed-dome technology is } \\
\text { known to be reliable and have been } \\
\text { working in various developing Asian } \\
\text { countries such as Bangladesh, Cambodia, } \\
\text { Laos, Pakistan, Nepal, and Vietnam }\end{array}$ \\
\hline
\end{tabular}


Table 5. Cont.

Case Study No. Background
Basic Features of Operation and Maintenance

- Capacity: Medium-large

- Substrate: 25 TPD Chicken dung, $200 \mathrm{~m}^{3} / \mathrm{d}$ pig slurry, 9 TPD Napier grass.

- $\quad$ Geographical location: Philippines (Bantayan Island, Cebu)

5

- Key partners/implementers:

Private sector

- Year of start: 2017
- Operation: Dual digester

- Digestate use: soil conditioner

- Energy generation: $400 \mathrm{~kW}$-el capacity, heating for animal farming

- Costs: Revenue from feeding electricity to the grid and self-use for the animal husbandry

- Other relevant information: Located in an island where electricity supply is unstable and national electricity price is high

Lessons Learned/Sustainability Factors

- Responding and providing solutions to the following problems: 1 . High electricity cost, 2. Electricity instability, 3. Odor pollution, 4 . Soil and water pollution that would occur if the animal waste was landfilled

- Technology was supplied and assisted by AD technology experts

- $\quad$ Periodic online meetings and local visits of experts for quality inspections and maintenance

- Immediate benefit to the farm (increased productivity of the egg layers and the pigs because power interruptions are avoided)

- Production of organic fertilizer from the digestate generated by the biogas plant

- $\quad$ Electricity Feed-in to the grid contributes an improvement to the island's grid stability

- Capacity: Medium-large (20 TPD)

- Substrate: vegetable and fruit waste from market waste

- Operation: Fermenter temperature at $35^{\circ} \mathrm{C}$ stirring is performed using mechanical, hydraulic or pneumatic equipment, gas is upgraded to bio-Compressed Natural Gas (bio-CNG).

location: India Madhya Pradesh)

- Key partners/implementers: Private sector and local government

- Year of start: 2017
Digestate use: Bio-slurry for agricultural use

- Energy generation: Electricity for self-consumption, Bio-CNG for city bus fuel.

- Costs: Investment under PPP mechanism

- Other relevant information: Pre-treatment to separate unwanted debris is performed in the Material Recovery Facility (MRF)
- Guaranteed purchase and price from the government for the bio-CNG is one key financial sustainability factor of these plants

- Intensive efforts made for socialization of waste segregation and daily collection especially for the municipal waste-based plant played significant role in securing a high purity of organic waste and smooth collection.

- Cooperation with the other private sector to improve digestate quality to meet the fertilizer standards set by the government had made it possible to sell the digestate as fertilizer at profitable price. 
Table 5. Cont.

\begin{tabular}{|c|c|c|c|}
\hline Case Study No. & Background & Basic Features of Operation and Maintenance & Lessons Learned/Sustainability Factors \\
\hline 7 & $\begin{array}{l}\text { - Geographical location: India } \\
\text { (Kabitkhedi, Indore, Madhya Pradesh) } \\
\text { - Key partners/implementers: Private } \\
\text { sector and local government } \\
\text { - Year of start: } 2018\end{array}$ & $\begin{array}{l}\text { - Capacity: Medium-large (15 TPD) } \\
\text { - } \quad \text { Opubstrate: Municipal organic waste } \\
\text { stirring is performed using mechanical, } \\
\text { hydraulic or pneumatic equipment, gas is } \\
\text { upgraded to bio-CNG. } \\
\text { - } \quad \text { Digestate use: Bio-slurry for agricultural use } \\
\text { - } \quad \text { Energy generation: Electricity for } \\
\text { - } \quad \text { celf-consumption, Bio-CNG for city bus fuel. } \\
\text { - } \text { Other relevant information: There are transit } \\
\text { stations located no more than } 10 \mathrm{Km} \text { from } \\
\text { waste sources where waste is packed into } 20 \\
\mathrm{~m}^{3} \text { size blocks before transported to the } \\
\text { digestion site. }\end{array}$ & \\
\hline
\end{tabular}




\subsection{China Case Study}

We interviewed a large-scale biogas plant located in Zhejiang Province, Shaoxing City, China. The capacity of the plant is 547 TPD (the substrate used consists of 370 TPD food waste from restaurants and 177 TPD kitchen waste collected from households in Yuecheng, Shangyu and Keqiao districts in Shaoxing city. The plant generates about $14,000 \mathrm{~m}^{3}$ of biogas per day converted into $28,000 \mathrm{kWh}$ of electricity. As part of the pre-treatment process, oil is extracted from the substrate with yield rate around 5 to 6 tons of oil per day. Under a PPP project construction mode, the plant cost around 270 million CNY (around 32 million USD).

The operating company works together with the local government to collect the waste from the sources using their own garbage collection vehicles equipped with Global Positioning System (GPS) as well as the government's garbage collection vehicle. After passing the waste reception facility, waste is screened using mechanical separation techniques to separate the light and heavy substances (such as bones, thick plastics, and metals). The extracted oil is sold as industrial and biodiesel materials. Buyers of this oils are enterprises that have passed an examination that checks the compatibility of their industry to use the oil. Example of the oil use is as raw material of soaps, biodiesels, and the aviation industry. After these pre-treatment processes, waste is fed into the AD system. The biogas produced by the AD system is used to generate electricity that is sold to the grid at the regional FIT rate which is $0.52 \mathrm{CNY} / \mathrm{kWh}$ (about $0.074 \mathrm{USD} / \mathrm{kWh}$ ) in Shaoxing City. At the final end, the digestate is separated based on their quality. The high quality organic solid waste is used for soil enrichment in the agriculture while the rest of the solid is transported to the incinerator in the domestic waste disposal center of the city. The wastewater is treated in the nearby sewage treatment facility. The process flow diagrams are shown in Figures 2 and 3.

Income from selling extracted oil in this plant is an aspect that does not exist in our other case studies. The plant is expecting an even better economic benefits following the deepening of China's waste segregation policy so that they can reduce cost from the pre-treatment processes.

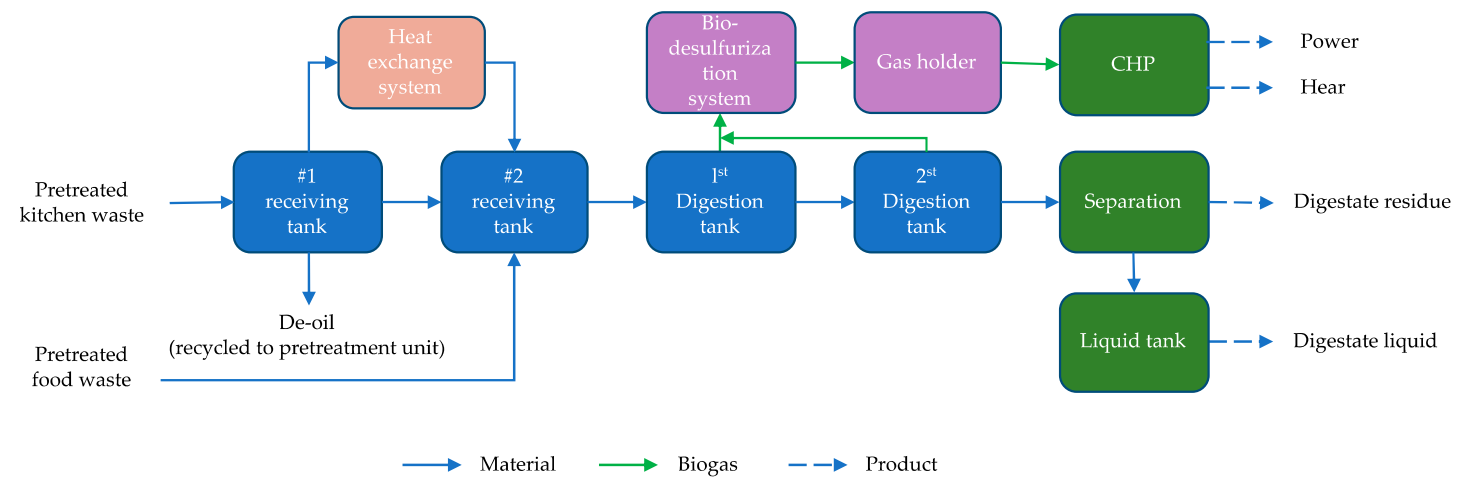

Figure 2. Material flow at the Shaoxing Plant (The diagram was drawn by Hangzhou Energy and Environmental Engineering Co., Ltd (HEEE) for this journal article). 


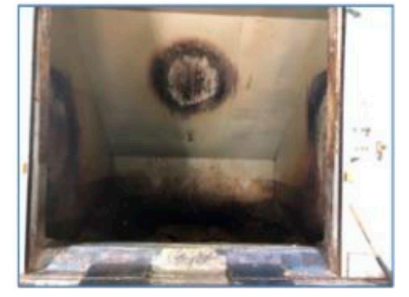

R eceiv ing hopper

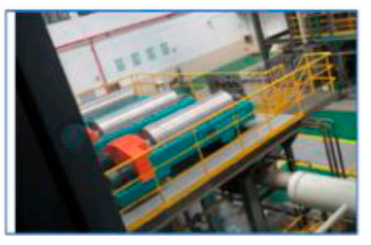

Three-phase oil extraction

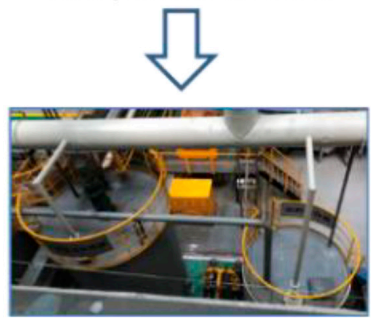

Three-phase slurry collection tank + o il collection tank

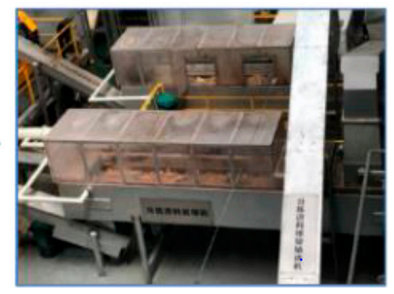

Screw conveyor + sorting feed belt

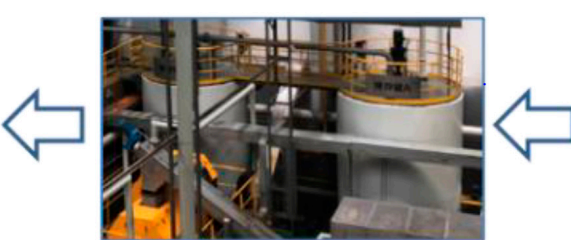

Slurry bu ffer tank

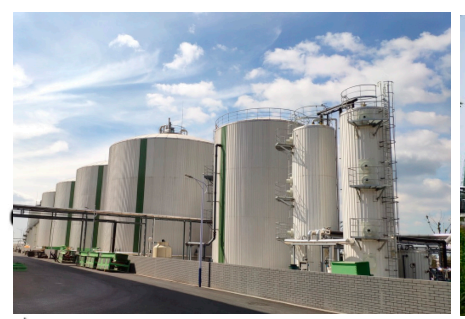

Anaerobic digestion unit

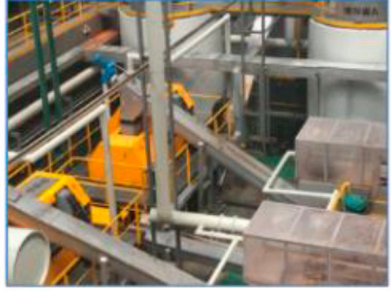

Sorting $m$ ach ine

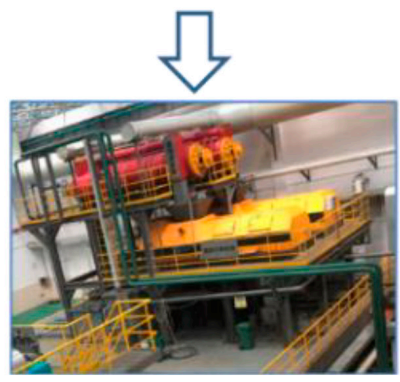

Therm alhydrolysis + separation

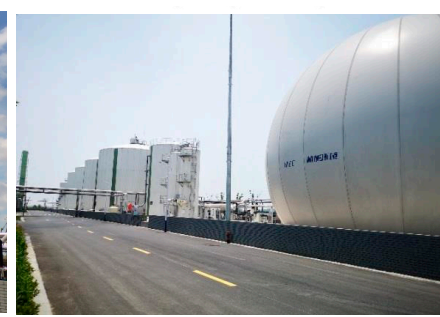$$
\text { nit }
$$

Figure 3. Detailed pre-treatment and AD unit photographs at the Shaoxing Plant (prepared by HEEE for this journal article).

\subsection{Japan Case Studies}

We interviewed two Japanese case studies in the medium-large capacity ranges. The first one is located in Oki Town, Fukuoka Prefecture. At the beginning of the 2000s, the town was faced with pressure to make a transition from waste to source management. The pressure came from financial constraints and the new regulation ("Waste Management Act") introduced in 2002 that banned disposal of human waste and septic tank sludge into the sea. These conditions pushed the town to reduce the cost for waste management by installing a biogas plant in 2006, to facilitate the transition from conventional incineration-based waste management to recycling-oriented resource management of organic waste. Organic kitchen waste recycling plan has been proposed by the town's mayor since 1999 and the biogas pilot project has been implemented from 2001 to 2003 [105]. The material flow of this plant is shown in Figure 4. Daily input of the plant is $3.8 \mathrm{t}$ of kitchen waste mixed with $7 \mathrm{t}$ of human waste and $30.6 \mathrm{t}$ of septic tank sludge. Using medium temperature with a retention time of 22 days, the plant generates $490 \mathrm{Nm}^{3}$ daily resulting in $697 \mathrm{~kW} /$ day of combined heat and power. The digestate is used as soil conditioner in the nearby rice paddies fields. The key sustainability factors of this plant were found to be the following: (1) Good leadership practice, (2) Local inclusiveness, (3) Reliable separation and collection practice, (4) Co-digestion, and (5) Integrated technology transition with the social transition. 


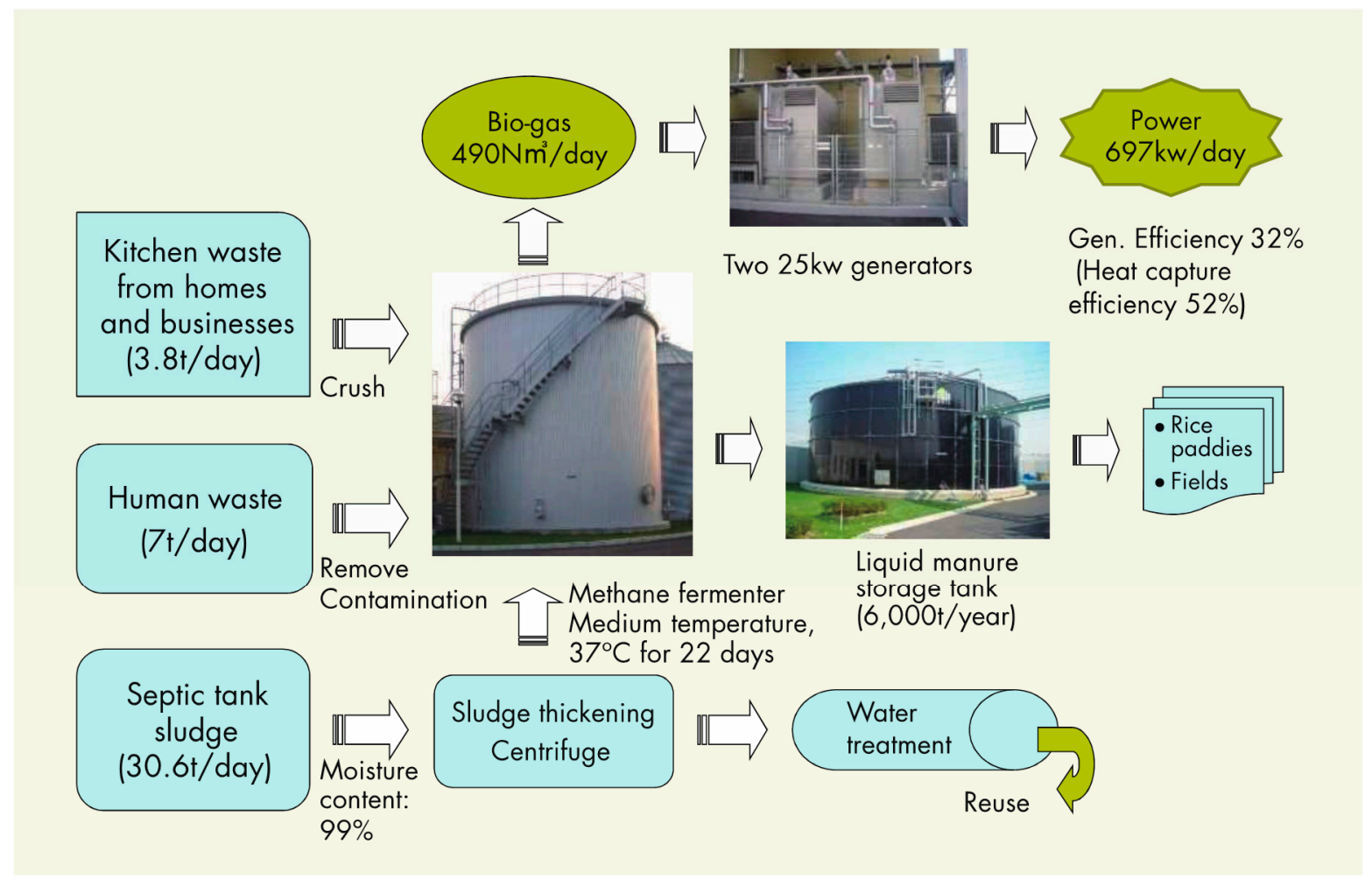

Figure 4. Material flow at Oki Town biogas plant. Source: [105].

The second Japan case study is located in Ota Ward, Tokyo city with an input capacity of 130 Ton Per Day (TPD) of supermarket and convenience food waste. The plant generated 26,880 kWh electricity/day and $2400 \mathrm{~m}^{3}$ city gas/day. Although the digestate is being incinerated due to lack of soil conditioner demand due to its metropolitan location, it allows energy recovery before the final disposal resulting in economic gains before waste is incinerated. The plant allows the reception of food waste still in its plastic or metal packaging because it is equipped with mechanical facilities to effectively separate the food waste contents from their containers (Figure 5). The key sustainability factors of this plant were found to be the following: (1) Government support for the initial investment costs, (2) Guarantee of income from FIT from the government and gate fee from the private sectors who dispose the food waste, (3) High demand for city gas, and (4) Reliable MBT technology effective for unpacking food waste. 


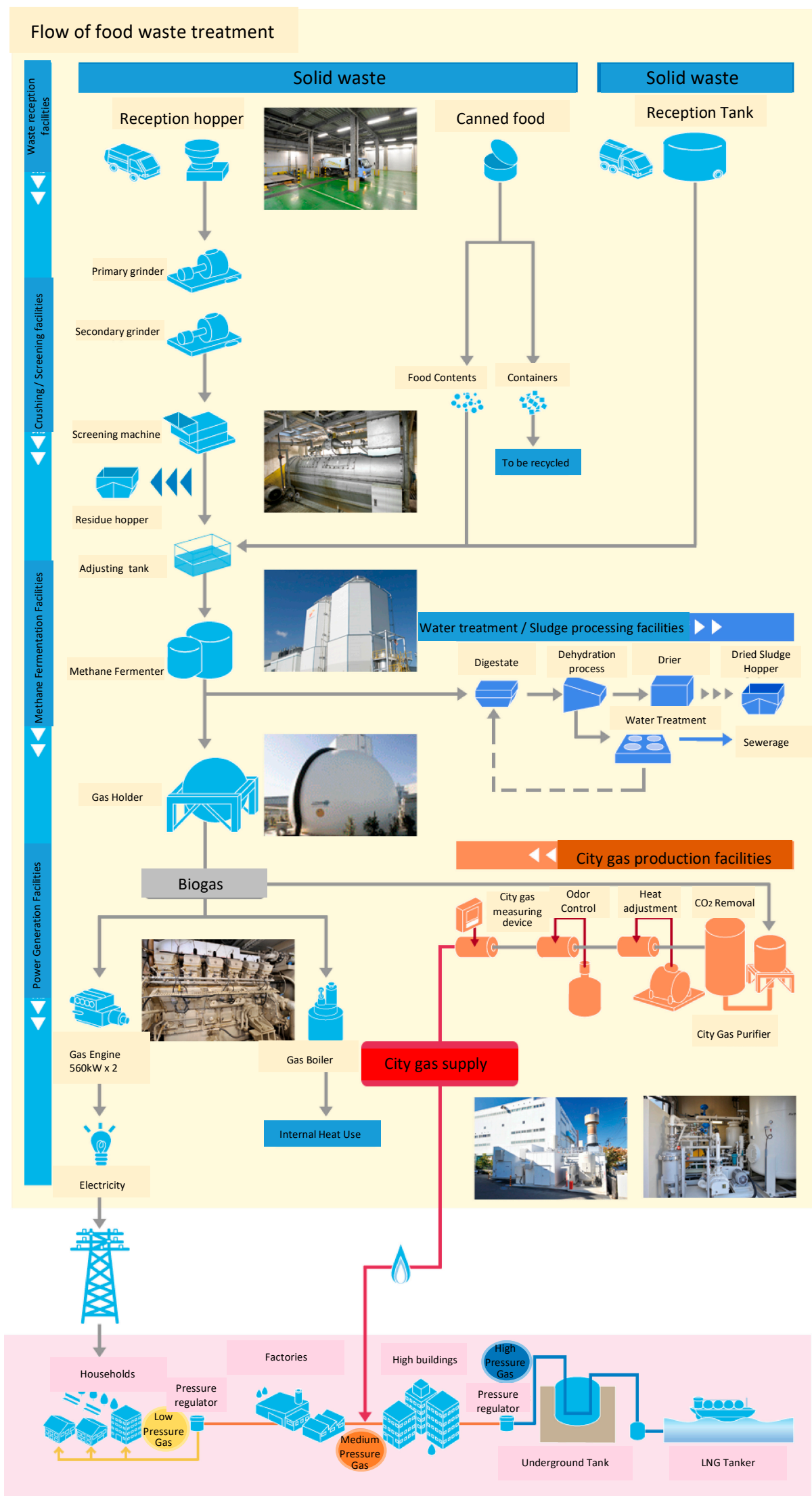

Figure 5. Material flow at the biogas plant in Tokyo (Source: [106], translated and used with permission from BIOENERGY Corp.). 


\subsection{Indonesia Case Study}

Small size biogas plants dominate the practice in Indonesia with 14,173 plants in nine provinces initiated by the Netherlands Development Organization (SNV). A simple fixed-dome digester is used in the projects using mainly animal manure or organic waste from the small-scale food industry (tofu). Technology-wise, such practice is in the highest possible maturity level, especially in the developing Asian region. Sustainability factors rely on the following; (1) Strong support from the government, (2) Reward system made by the organization to motivate operator to sustain the plant, (3) Technical assistance available especially during the first year of operation, and (4) Appropriate demand for the output energy and digestate. The rural location of many of the biogas plants in this project made choosing to use energy from biogas plants an easy choice. When there is no competing highly subsidized electricity or cooking fuel (usually Liquified Petroleum Gas(LPG)), there is significant demand to use energy generated from biogas plant for lighting and cooking. Moreover, many of the animal farmers either own their own agricultural field to use the digestate as a soil conditioner or have a neighbor that has such demand (Figure 6).

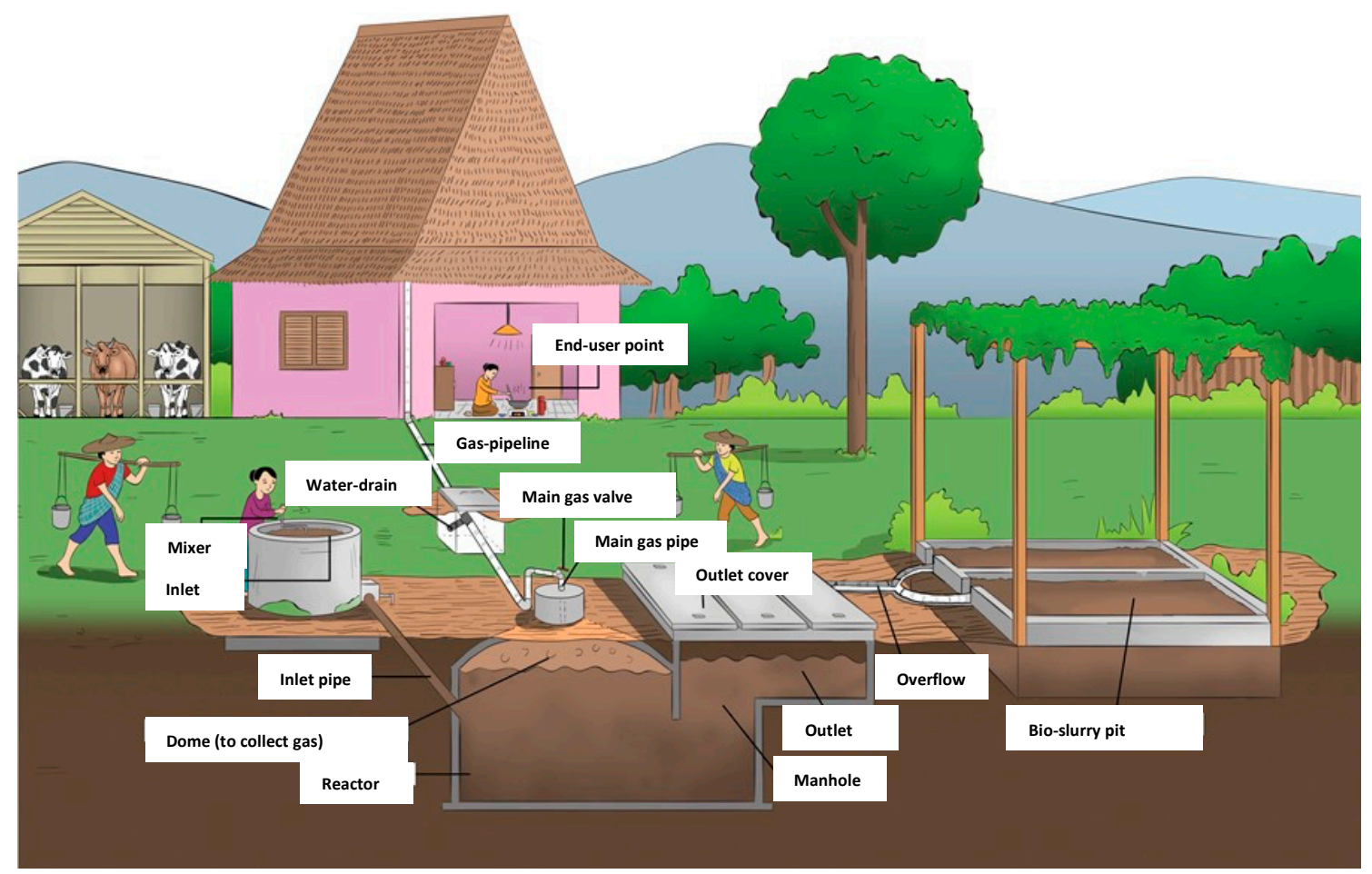

Figure 6. Material flow at an Indonesian household scale biogas plant. Source: [107] (Used with permission from BIRU).

\subsection{Philippines Case Study}

The Philippines case study operates in medium-large capacity using a combination of animal waste and unutilized biomass (co-digestion) in Bantayan Island, Cebu. With an input capacity of $25 \mathrm{TP}$ of chicken dung, $200 \mathrm{~m}^{3} / \mathrm{d}$ of pig slurry, and 9 TPD of Napier grass, the dual digesters generate $400 \mathrm{KW}_{\mathrm{el}}$ capacity (Figure 7). Electricity price in the Philippines is among the highest in Asian countries, therefore there is a high incentive for the operator to internally use it in their farming facility. The location of the plant on a small island where electricity is not stable is also a significant sustainability factor because the plant provides an immediate solution. The heat generated is used to keep the farm animal warm and improve their productivity. Excess of electricity is fed to the grid and this contributes to the improvement of the island's grid stability as well as a good income for the plant through the FIT mechanisms. 


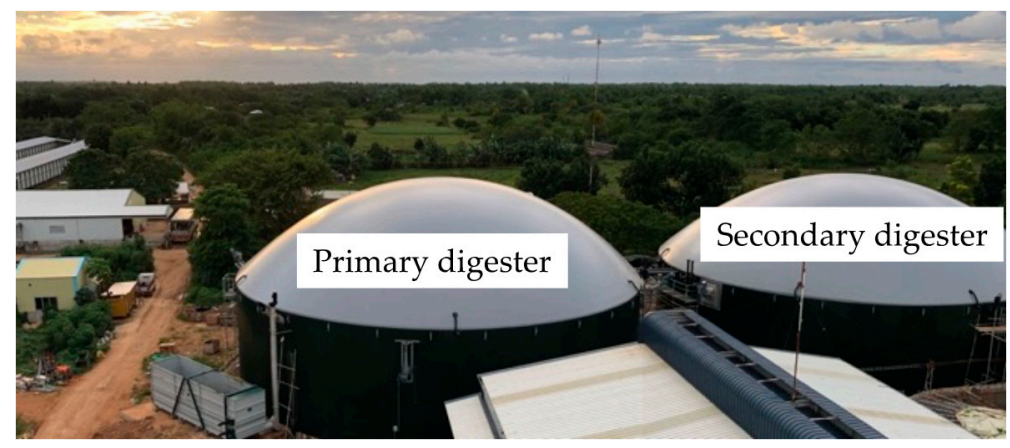

Figure 7. Dual digester of the Philippines case study biogas plant (used with permission from PlanET Biogastechnik $\mathrm{GmbH}$.).

\subsection{India Case Study}

There are two biogas plants in Indore, Madhya Pradesh, India, that are operated by the same company, called Eco Pro Environmental Services (Figure 8). The first one is in Choithram Mandi with a capacity of 20 TPD using vegetable and fruit market waste as feedstock, and the second one is in Kabitkhedi with a capacity of 15 TPD using municipal organic waste. Both plants main utilized output is bio-Compressed Natural Gas (Bio-CNG), which is an upgraded biogas that is on par with natural gas and usable as vehicle fuel. The land of these plants was provided by the government. A key success factor of these plants is a strong involvement of key stakeholders for project planning and commissioning. For example, the land of these plants were provided by the local government, local non-governmental organizations (NGOs) provide a socialization of waste segregation and door-to-door waste collection system, residents separate waste at source into wet and dry making it easy for collectors, and the national government has set a minimum selling price guaranteeing for selling of Bio-CNG which is the final products of the plant. In addition, the local government and fertilizer companies help in selling the organic compost fertilizer and liquid fertilizer.

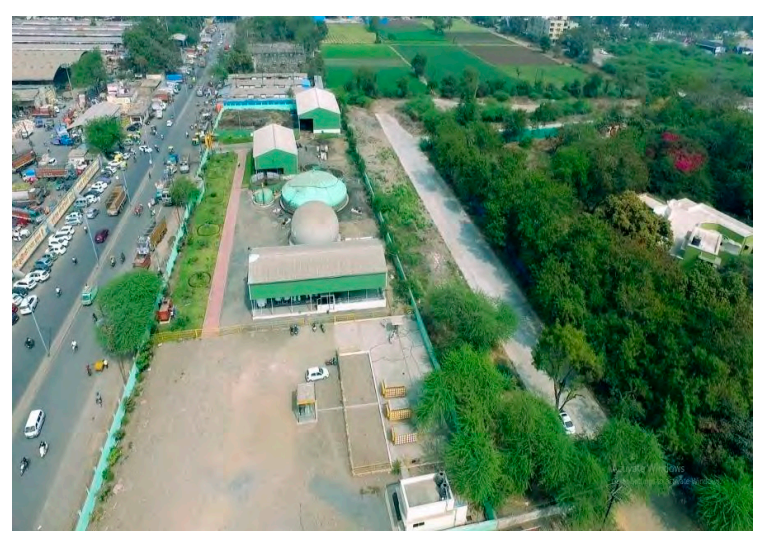

(a)

Figure 8. Cont. 


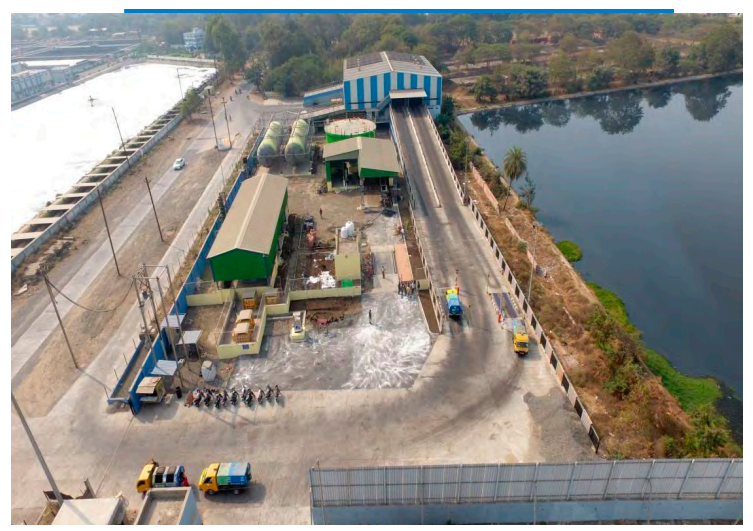

(b)

Figure 8. Bio-CNG-generating biogas plants in Indore, Madhya Pradesh, India. (a) Choithram Mandi plant (20 TPD capacity using fruit and vegetable market waste), (b) Kabitkhedi plant (15 TPD capacity using organic municipal household waste) (used with permission from Eco Pro Environmental Services).

\section{Implementation Framework for Sustainable Municipal Organic Waste Management using Biogas Plants in Emerging Countries in Asia}

Learning from the literature reviews and interviews with sustainably operating biogas plant managers from the five countries elaborated in the previous sections, we developed a framework that could be used to guide biogas project planners in implementing a sustainable biogas plant using municipal organic waste in emerging countries in Asia (Figure 9). The framework contains six elements with a number of check points in each element.

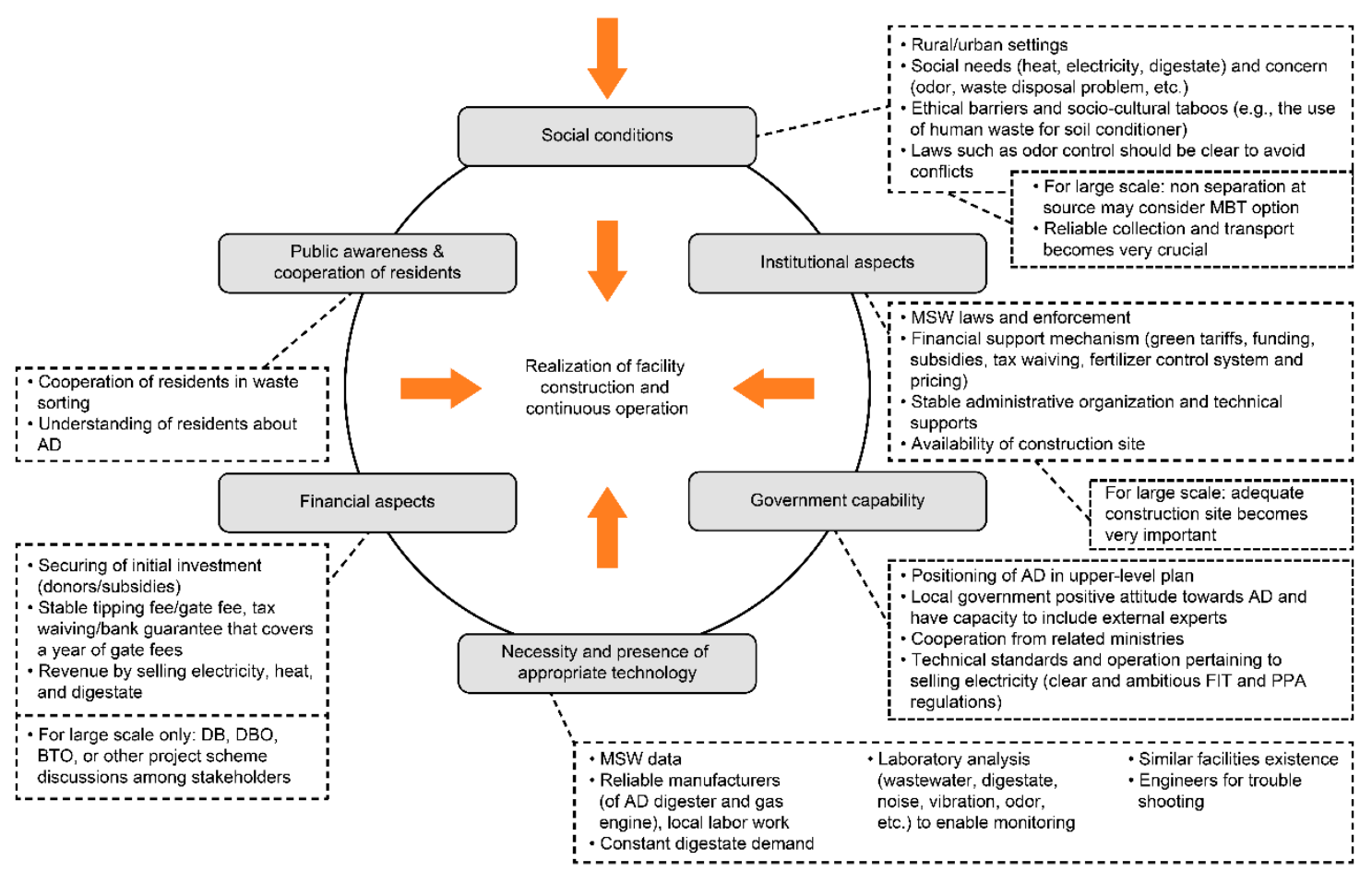

Figure 9. Implementation framework for sustainable municipal organic waste management using biogas plants in emerging countries in Asia. 


\subsection{Social Conditions}

To determine whether social conditions are suitable for biogas plant project implementation, the following information should be considered: (1) whether the location is rural or urban [24]; (2) social needs (heat, electricity, and digestate) and concerns (odor, waste disposal problems, etc.) $[25,55,77,78,108]$; and (3) ethical barriers and socio-cultural taboos (e.g., the use of human waste as soil conditioner) $[8,18,30,34,72]$. Determining whether a location is rural or urban is important in estimating the appropriate scale and technologies for a project. Characteristics and amounts of municipal waste generated in urban settings are quite different from those generated in rural areas. For example, urban municipal waste may contain more manufactured goods, packaging, and inert waste while rural waste may contain less of these in the total volume. The urban/rural context also indicates how established and convenient infrastructure and facilities are in the area. This information is crucial for determining whether waste from various locations could be transported to feed one medium or large-scale biogas plant or whether it is better to utilize smaller plants positioned close to the waste source.

To anticipate competition with more convenient or cheaper alternatives, it is also important to determine heat, electricity, and digestate requirements. Odor and other waste management-related social problems must also be identified. Odor prevention methods may be introduced when problems are anticipated or exist in a given area. Those who handle waste should also be identified to determine which stakeholders to target when waste separation systems are to be socialized.

\subsection{Institutional Aspects}

The sustainability of a biogas plant project can be compromised when there is no supporting system running in the background. In the emerging Asian region, a biogas plant project may be sensitive to the following institutional issues: (1) MSW laws and enforcement $[49,60,77,93]$, (2) financial support mechanisms (green tariffs, funding, subsidies, tax waving, fertilizer control systems and pricing) $[22,24,25,28,69,93,94]$, (3) stable administrative organizations and technical support [72-75], and (4) construction site availability [31,35,72]. These aspects shape the sustainability of biogas plants in various ways. For example, without stringent laws and implementation standards, pure of organic feedstock is not achievable, and without financial support mechanisms, financial sustainability cannot be ensured.

In addition to financial support, technical support is crucial especially in emerging Asia. Sustainability can be improved when technical assistance is made available especially in the early years of a biogas plant's lifetime.

\subsection{Public Awareness and Cooperation from Residents}

The success of using municipal solid waste in a biogas plant also depends on cooperation from residents in terms of waste sorting and in terms of their understanding of biogas technology. A plant's success is attributed to a technological transition running in parallel with a social transition where continuous socialization has been executed to ensure that residents understand the shift from waste management based on incineration and sea disposal to one based on biogas. This aspect was found to be an important sustainability factor especially in the Oki Town and the India biogas plant case studies presented in the previous section.

\subsection{Government Capabilities}

It is undeniable that good governance can mobilize new regulations and their implementation. Good governance is also crucial to the sustainability of a municipal solid waste biogas plant. Governments are expected to show a positive attitude towards the use of biogas technology by creating regulations that support biogas implementation. Governments can do this by prioritizing waste management laws, through the dissemination of information to build awareness in local governments, and through cooperation with related ministries (e.g., with ministries of agriculture in 
relation to the use of digestate) [108]. In energy departments and electric power companies, technical standards and operations pertaining to the selling of electricity and to its selling price should be set forth. To ensure financial viability, clear and ambitious feed-in rules and/or comprehensive green Power Purchase Agreements (PPAs) are necessary. Most of the case studies interviewed in this study found that the government plays a vital role in driving aspects that contributes to the plant's financial sustainability.

\subsection{Financial Considerations}

The financial issues are often the main concern of many biogas plant investors in the emerging Asia region. Some key financial elements especially central to the implementation of biogas in this region include the following: (1) securing initial investment (donors/subsidies) [19,34,55,73,75,92]; (2) stable tipping /gate fees and tax waving/bank guarantees that cover annual gate fees $[24,44,46,50])$; (3) revenues generated by selling electricity, heat, and digestate [28,31,41,42,44,50,59,69]; and (4) for large scale AD projects, Design-Build-Operate (DBO) and Build-Operate-Transfer (BOT) project schemes discussed among stakeholders $[8,33,77]$. Collaboration with various stakeholders is key to financial and technical capacity.

\subsection{The Need for and Presence of Appropriate Technologies}

Finally, to ensure that biogas is the appropriate technology to apply to a given location, it is important to clarify the need for and presence of similar technologies in the area [34]. Based on our case study interviews, one must obtain basic data and information pertaining to waste (the amount and composition of waste, waste treatment processes, temporary dumping sites, transport to final Municipal Solid Waste Management (MSWM) locations, etc.). For larger projects, reliable manufacturers (of biogas digesters and gas engines) may be expected to participate. Participation in construction and operations and in early maintenance may be required. Some biogas plants must be supported with local labor and this opportunity should be optimized. Training can be offered to close skills gaps and enhance dissemination. Laboratories for the analysis of wastewater, digestate, noise, vibrations, odor, etc. should be developed for appropriate monitoring. Ideally, the existence of such facilities should build confidence in the use of this technology. Even when different feedstock is used, (e.g., biogas plants using animal manure and agricultural waste), when such plants exist and are managed appropriately, this may serve as an indicator of a community's acceptance of biogas technology.

\section{Summary and Avenues for Future Research}

Previous studies on the implementation of AD technology have focused on topics such as technical issues [21,22], the national scope [14,23-25], the European region [26-28], and cross-sectional reviews of the sustainability of renewable energy practices in developing countries [19]. Our study focused on organic waste biogas plant implementation and summarized approaches based on three challenge categories-technical, financial, and social-supporting the construction of a sustainability framework relevant to the developing Asian region. This region was studied due to the untapped material and energy recovery potential of organic waste generated from municipalities and to address the growing challenges related to waste management resulting from rapid population growth in this region.

Based on a qualitative literature review and interviews with sustainably running biogas plants in five different countries in the world, we first presented the results as separate challenges and then organized them into a framework of elements necessary for the sustainable implementation of municipal solid waste biogas in emerging Asian countries. The most critical sustainability factors of a biogas plant project found in this study are the following:

(1) Sustainable supply of suitable quality and amount of organic waste substrates as well as sustainable demand for the digestate must be secured and maintained throughout the operation of the biogas plant. 
(2) Technical assistance from professionals is required during the design, construction, and the first years of operation of the plant.

(3) A desirable financial environment must be created to guarantee the financial sustainability of the plant. To create such an environment, both the public and the private sectors must play their most ambitious roles in cooperative manners.

(4) Government regulations and its implementation in various areas (waste segregation policy, FIT, fertilizer quality control and pricing, tipping fee, etc.) play significant role in creating the desirable technical, financial, and social environment to sustain a biogas plant using municipal waste nationally.

In our proposed framework, the key sustainable elements are as follows: (1) social conditions, (2) institutional aspects, (3) public awareness and cooperation from residents, (4) government capabilities, (5) financial aspects, and (6) demand for and the presence of appropriate technologies.

This review highlights a number of avenues for further research. The first avenue relates to a need for an understandable and applicable step-by-step guide that can assist practitioners in creating the conditions required to scale up municipal waste-based biogas plants in emerging Asia. The second avenue relates to a need for information about budget requirement to establish different scales of biogas plants, capital turnover projections, and a list of possible loopholes of the finance during the construction and operation of the biogas plant. The third avenue responds to the current lack of research in technologies that can identify substrate toxicants and inhibitors before waste enters the digester and its appropriate pre-treatment techniques. The fourth avenue concerns how a willingness to sustain biogas plants and a sense of ownership among biogas plant operators can be ensured as well as the identification of committed stakeholders in creating sustainable teams that will manage and operate biogas plants in the long term. The fifth avenue relates to the business end of municipal waste-based biogas plants. If the operation of municipal waste-based biogas plants could be rendered financially attractive and sustainable through the development of an innovative business plan, people would be driven to handle technical and social issues to allow the technology to work. Eventually, as organic waste represents more than half of municipal solid waste in the region, the more organic solid municipal waste that is materially and energetically recovered through biogas technologies, the closer the region can come to developing a circular economy.

Author Contributions: Conceptualization, A.H.P., P.J.D.G., and C.L.; data curation, A.H.P.; formal analysis, A.H.P.; funding acquisition, A.H.P., P.J.D.G., and C.L.; Investigation, A.H.P, P.J.D.G., C.L., and Y.G.; methodology, A.H.P., P.J.D.G., and C.L.; Validation, P.J.D.G.; writing—original draft preparation, A.H.P.; writing-review and editing, A.H.P., and Y.G.; visualization, A.H.P. and C.L.; supervision, M.K. and H.O.; project administration, A.H.P., Resources, A.H.P., P.J.D.G., C.L., and F.M.

Funding: This study was supported by the IGES Centre Collaborating with UNEP on Environmental Technologies (CCET) under a project for the development and deployment of guidelines on selected waste management (PCA2-2-1). The APC was funded by Waseda University.

Acknowledgments: The authors thank plant managers interviewed in the process of constructing this paper; Agung Lenggono, technical specialist of Rumah Energi, Indonesia; Ajeng Kusumaningtyas Pramono, business developer at Bioenergy, Japan; Jakob Hildebrandt, assistant plant manager at Kompotec, Germany; Athaydes Leite, International Key Account Manager at PlanET Biogastechnik, Germany and their client from Wellisa plant in the Philippines; Syed Asad Ali Warsi, Founder and Director of Eco Pro Environmental Services, India, Tan Jing, General manager assistant from Hangzhou Energy and Environmental Engineering Co., Ltd., China, and other informants from AMITA and Kururun project in Okitown, Japan. We are also grateful for the feedback received from waste management experts during our special session in 3RINCs conference, Bangkok, in February 2019, and the "Technology Solutions for Holistic Waste Management - A Global Dialogue with the Private Sector" summit in Osaka, in May 2019.

Conflicts of Interest: The authors declare no conflict of interest. 


\section{References}

1. Abbasi, T.; Tauseef, S.M.; Abbasi, S.A. Biogas Energy; Springer: Berlin/Heidelberg, Germany, 2012; pp. 1-169.

2. Martineau, V.; Worley, J. Introduction to Biogas. 2009. Available online: http://rosalieforest.com/ biogasworkshop-may4thv2.ppt (accessed on 10 March 2019).

3. The Role of Waste-to-Energy in the Circular Economy; Communication from the Commission to the European Parliament, the Council, the European Economic and Social Committee and the Committee of the Regions, European Commission: Brussels, Belgium, 2017.

4. Closing the Loop-An EU action plan for the Circular Economy; Communication from the Commission to the European Parliament, the Council, the European Economic and Social Committee and the Committee of the Regions, European Commission: Brussels, Belgium, 2015.

5. Fagerström, A.; Seadi, A.; Rasi, T.; Briseid, S. The Role of Anaerobic Digestion and Biogas in the Circular Economy; IEA Bioenergy Task 37: Cork, Ireland, 2018; Volume 37.

6. Nizami, A.S.; Rehan, M.; Waqas, M.; Naqvi, M.; Ouda, O.K.M.; Shahzad, K.; Miandad, R.; Khan, M.Z.; Syamsiro, M.; Ismail, I.M.I.; et al. Waste biorefineries: Enabling circular economies in developing countries. Bioresour. Technol. 2017. [CrossRef] [PubMed]

7. Nizami, A.; Rehan, M.; Waqas, M.; Naqvi, M.; Ouda, O.; Shahzad, K.; Miandad, R.; Khan, M.; Syamsiro, M.; Ismail, I.; et al. Waste biorefineries: Enabling circular economies in developing countries. Bioresour. Technol. 2017, 241, 1101-1117. [CrossRef] [PubMed]

8. World Bank. What a Waste 2.0; The World Bank: Washington, DC, USA, 2018.

9. Asia-Pacific Human Development Report; UNDP: New York, NY, USA, 2016.

10. Gu, L.; Zhang, Y.-X.; Wang, J.-Z.; Chen, G.; Battye, H. Where is the future of China's biogas? Review, forecast, and policy implications. Pet. Sci. 2016, 13, 604-624. [CrossRef]

11. Biogas Country Overview; IEA Bioenergy Task 37: Cork, Ireland, 2010.

12. Biomethane, E.B.A. Biogas Report. European Biogas Association. 2015. Available online: http://europeanbiogas.eu/2015/12/16/biogasreport2015/ (accessed on 13 March 2019).

13. Bond, T.; Templeton, M.R. History and future of domestic biogas plants in the developing world. Energy Sustain. Dev. 2011, 15, 347-354. [CrossRef]

14. Chen, Y.; Yang, G.; Sweeney, S.; Feng, Y. Household biogas use in rural China: A study of opportunities and constraints. Renew. Sustain. Energy Rev. 2010, 14, 545-549. [CrossRef]

15. Asian Development Bank. ADB-Funded Biogas Plants to Tackle Viet Nam's Growing Rural Waste Threat. 2012. Available online: https://www.adb.org/news/adb-funded-biogas-plants-tackle-viet-nams-growingrural-waste-threat (accessed on 13 March 2019).

16. Rumah Energy. BIRU Programme-Rumah Energi. 2015. Available online: http://www.biru.or.id/en/index. php/biru-program/ (accessed on 13 March 2019).

17. World Bank. Projects: Nepal-Biogas Program. 2017. Available online: http://projects.worldbank.org/ P090038/nepal-biogas-program?lang=en (accessed on 13 March 2019).

18. Hirmer, S.; Cruickshank, H. The user-value of rural electrification: An analysis and adoption of existing models and theories. Renew. Sustain. Energy Rev. 2014, 34, 145-154. [CrossRef]

19. Terrapon-Pfaff, J.; Dienst, C.; König, J.; Ortiz, W. A cross-sectional review: Impacts and sustainability of small-scale renewable energy projects in developing countries. Renew. Sustain. Energy Rev. 2014, 40, 1-10. [CrossRef]

20. Hong, G.W.; Abe, N.; Baclay, M.; Arciaga, L. Assessing users' performance to sustain off-grid renewable energy systems: The capacity and willingness approach. Energy Sustain. Dev. 2015, 28, 102-114. [CrossRef]

21. Khan, I.U.; Othman MH, D.; Hashim, H.; Matsuura, T.; Ismail, A.F.; Rezaei-DashtArzhandi, M.; Azelee, I.W. Biogas as a renewable energy fuel-A review of biogas upgrading, utilisation and storage. Energy Convers. Manag. 2017, 150, 277-294. [CrossRef]

22. Miltner, M.; Makaruk, A.; Harasek, M. Review on available biogas upgrading technologies and innovations towards advanced solutions. J. Clean. Prod. 2017, 161, 1329-1337. [CrossRef]

23. Khan, E.U.; Martin, A.R. Review of biogas digester technology in rural Bangladesh. Renew. Sustain. Energy Rev. 2016, 62, 247-259. [CrossRef]

24. Mittal, S.; Ahlgren, E.O.; Shukla, P.R. Barriers to biogas dissemination in India: A review. Energy Policy 2018, 112, 361-370. [CrossRef] 
25. Yasar, A.; Nazir, S.; Rasheed, R.; Tabinda, A.B.; Nazar, M. Economic review of different designs of biogas plants at household level in Pakistan. Renew. Sustain. Energy Rev. 2017, 74, 221-229. [CrossRef]

26. Lindkvist, E.; Karlsson, M. Biogas production plants; existing classifications and proposed categories. J. Clean. Prod. 2018, 174, 1588-1597. [CrossRef]

27. Scarlat, N.; Dallemand, J.F.; Fahl, F. Biogas: Developments and perspectives in Europe. Renew. Energy 2018, 129, 457-472. [CrossRef]

28. Torrijos, M. State of Development of Biogas Production in Europe. Procedia Environ. Sci. 2016, 35, 881-889. [CrossRef]

29. Denyer, D.; Tranfield, D. Using qualitative research synthesis to build an actionable knowledge base. Manag. Decis. 2006, 44, 213-227. [CrossRef]

30. Gabriel, C.A. What is challenging renewable energy entrepreneurs in developing countries? Renew. Sustain. Energy Rev. 2016, 64, 362-371. [CrossRef]

31. Guide to Biogas: From Production to Use; FNR: Gülzow, Germany, 2010.

32. Biogas Digest IV; GTZ: Eschborn, Germany, 1999.

33. Converting Biomass to Energy; IFC: Washington, DC, USA, 2017.

34. Kossmann, W.; Pönitz, U. Biogas Digest Volume I: Biogas Basics; GTZ: Eschborn, Germany, 1999.

35. Tanto, D.; Wiratni, B. Menembus Pagar Baja: Dimensi Sosial dalam Proses Difusi Teknologi Biogas; UGM Press: Jogjakarta, Indonesia, 2018.

36. World Bank. World Bank Country and Lending Groups. 2019. Available online: https://datahelpdesk. worldbank.org/knowledgebase/articles/906519-world-bank-country-and-lending-groups. (accessed on 18 March 2019).

37. Chaichana, C.; Wongsapai, W.; Damrongsak, D.; Ishihara, K.N.; Luangchosiri, N. Promoting Community Renewable Energy as a tool for Sustainable Development in Rural Areas of Thailand. Energy Procedia 2017, 141, 114-118. [CrossRef]

38. Aleluia, J.; Ferrão, P. Assessing the costs of municipal solid waste treatment technologies in developing Asian countries. Waste Manag. 2017, 69, 592-608. [CrossRef] [PubMed]

39. Indrawan, N.; Thapa, S.; Wijaya, M.E.; Ridwan, M.; Park, D.-H. The biogas development in the Indonesian power generation sector. Environ. Dev. 2018, 25, 85-99. [CrossRef]

40. Pradhan, B.B.; Limmeechokchai, B. Electric and Biogas Stoves as Options for Cooking in Nepal and Thailand. Energy Procedia 2017, 138, 470-475. [CrossRef]

41. Delzeit, R.; Kellner, U. The impact of plant size and location on profitability of biogas plants in Germany under consideration of processing digestates. Biomass Bioenergy 2013, 52, 43-53. [CrossRef]

42. Skovsgaard, L.; Jacobsen, H.K. Economies of scale in biogas production and the significance of flexible regulation. Energy Policy 2017, 101, 77-89. [CrossRef]

43. Trávníček, P.; Kotek, L.; Junga, P.; Vítěz, T.; Drápela, K.; Chovanec, J. Quantitative analyses of biogas plant accidents in Europe. Renew. Energy 2018, 122, 89-97. [CrossRef]

44. Yabe, N. Environmental and economic evaluations of centralized biogas plants running on cow manure in Hokkaido, Japan. Biomass Bioenergy 2013, 49, 143-151. [CrossRef]

45. Chen, Y.; Hu, W.; Chen, P.; Ruan, R. Household biogas CDM project development in rural China. Renew. Sustain. Energy Rev. 2017, 67, 184-191. [CrossRef]

46. Fei, F.; Wen, Z.; Huang, S.; de Clercq, D. Mechanical biological treatment of municipal solid waste: Energy efficiency, environmental impact and economic feasibility analysis. J. Clean. Prod. 2018, 178, 731-739. [CrossRef]

47. Zhang, Q.; Hu, J.; Lee, D.-J. Biogas from anaerobic digestion processes: Research updates. Renew. Energy 2016, 98, 108-119. [CrossRef]

48. Scheftelowitz, M.; Becker, R.; Thrän, D. Improved power provision from biomass: A retrospective on the impacts of German energy policy. Biomass Bioenergy 2018, 111, 1-12. [CrossRef]

49. Shane, A.; Gheewala, S.H.; Phiri, S. Rural domestic biogas supply model for Zambia. Renew. Sustain. Energy Rev. 2017, 78, 683-697. [CrossRef]

50. Hamzehkolaei, F.T.; Amjady, N. A techno-economic assessment for replacement of conventional fossil fuel based technologies in animal farms with biogas fueled CHP units. Renew. Energy 2018, 118, 602-614. [CrossRef] 
51. Auburger, S.; Petig, E.; Bahrs, E. Assessment of grassland as biogas feedstock in terms of production costs and greenhouse gas emissions in exemplary federal states of Germany. Biomass Bioenergy 2017, 101, 44-52. [CrossRef]

52. Ko, C.-H.; Chaiprapat, S.; Kim, L.-H.; Hadi, P.; Hsu, S.-C.; Leu, S.-Y. Carbon sequestration potential via energy harvesting from agricultural biomass residues in Mekong River basin, Southeast Asia. Renew. Sustain. Energy Rev. 2017, 68, 1051-1062. [CrossRef]

53. Onthong, U.; Juntarachat, N. Evaluation of Biogas Production Potential from Raw and Processed Agricultural Wastes. Energy Procedia 2017, 138, 205-210. [CrossRef]

54. Paudel, S.R.; Banjara, S.P.; Choi, O.K.; Park, K.Y.; Kim, Y.M.; Lee, J.W. Pretreatment of agricultural biomass for anaerobic digestion: Current state and challenges. Bioresour. Technol. 2017, 245, 1194-1205. [CrossRef] [PubMed]

55. Kabir, H.; Yegbemey, R.N.; Bauer, S. Factors determinant of biogas adoption in Bangladesh. Renew. Sustain. Energy Rev. 2013, 28, 881-889. [CrossRef]

56. Meyer, A.K.P.; Ehimen, E.A.; Holm-Nielsen, J.B. Future European biogas: Animal manure, straw and grass potentials for a sustainable European biogas production. Biomass Bioenergy 2018, 111, 154-164. [CrossRef]

57. Hossen, M.M.; Rahman, A.H.M.S.; Kabir, A.S.; Hasan, M.M.F.; Ahmed, S. Systematic assessment of the availability and utilization potential of biomass in Bangladesh. Renew. Sustain. Energy Rev. 2017, 67, 94-105. [CrossRef]

58. Roubík, H.; Mazancová, J.; Banout, J.; Verner, V. Addressing problems at small-scale biogas plants: A case study from central Vietnam. J. Clean. Prod. 2016, 112, 2784-2792. [CrossRef]

59. Roubík, H.; Mazancová, J.; Phung, L.D.; Banout, J. Current approach to manure management for small-scale Southeast Asian farmers-Using Vietnamese biogas and non-biogas farms as an example. Renew. Energy 2018, 115, 362-370. [CrossRef]

60. Shane, A.; Gheewala, S.H.; Kafwembe, Y. Urban commercial biogas power plant model for Zambian towns. Renew. Energy 2017, 103, 1-14. [CrossRef]

61. Grando, R.L.; Antune, A.M.d.; da Fonseca, F.V.; Sánchez, A.; Barrena, R.; Font, X. Technology overview of biogas production in anaerobic digestion plants: A European evaluation of research and development. Renew. Sustain. Energy Rev. 2017, 80, 44-53. [CrossRef]

62. Sgroi, F.; Foderà, M.; di Trapani, A.M.; Tudisca, S.; Testa, R. Economic evaluation of biogas plant size utilizing giant reed. Renew. Sustain. Energy Rev. 2015, 49, 403-409. [CrossRef]

63. Hosseinipour, S.A.; Mehrpooya, M. Comparison of the biogas upgrading methods as a transportation fuel. Renew. Energy 2019, 130, 641-655. [CrossRef]

64. Yang, L.; Ge, X.; Wan, C.; Yu, F.; Li, Y. Progress and perspectives in converting biogas to transportation fuels. Renew. Sustain. Energy Rev. 2014, 40, 1133-1152. [CrossRef]

65. Jain, S.; Jain, S.; Wolf, I.T.; Lee, J.; Tong, Y.W. A comprehensive review on operating parameters and different pretreatment methodologies for anaerobic digestion of municipal solid waste. Renew. Sustain. Energy Rev. 2015, 52, 142-154. [CrossRef]

66. Hagos, K.; Zong, J.; Li, D.; Liu, C.; Lu, X. Anaerobic co-digestion process for biogas production: Progress, challenges and perspectives. Renew. Sustain. Energy Rev. 2017, 76, 1485-1496. [CrossRef]

67. De Clercq, D.; Wen, Z.; Lu, X.; Caicedo, L.; Cao, X.; Fan, F. Determinants of efficiency in an industrial-scale anaerobic digestion food waste-to-biogas project in an Asian megacity based on data envelopment analysis and exploratory multivariate statistics. J. Clean. Prod. 2017, 168, 983-996. [CrossRef]

68. Zhang, L.; Loh, K.-C.; Zhang, J. Enhanced biogas production from anaerobic digestion of solid organic wastes: Current status and prospects. Bioresour. Technol. Rep. 2019, 5, 280-296. [CrossRef]

69. Tyagi, V.K.; Fdez-Güelfo, L.A.; Zhou, Y.; Álvarez-Gallego, C.J.; Garcia, L.I.R.; Ng, W.J. Anaerobic co-digestion of organic fraction of municipal solid waste (OFMSW): Progress and challenges. Renew. Sustain. Energy Rev. 2018, 93, 380-399. [CrossRef]

70. Astals, S.; Batstone, D.J.; Tait, S.; Jensen, P.D. Development and validation of a rapid test for anaerobic inhibition and toxicity. Water Res. 2015, 81, 208-215. [CrossRef] [PubMed]

71. Chen, J.L.; Ortiz, R.; Steele, T.W.J.; Stuckey, D.C. Toxicants inhibiting anaerobic digestion: A review. Biotechnol. Adv. 2014, 32, 1523-1534. [CrossRef] [PubMed]

72. Biogas-Application and Product; GTZ and ISAT: Eschborn, Germany, 1999. 
73. Bedi, A.S.; Sparrow, R.; Tasciotti, L. The impact of a household biogas programme on energy use and expenditure in East Java. Energy Econ. 2017, 68, 66-76. [CrossRef]

74. Ghimire, P.C. SNV supported domestic biogas programmes in Asia and Africa. Renew. Energy 2013, 49, 90-94. [CrossRef]

75. Roopnarain, A.; Adeleke, R. Current status, hurdles and future prospects of biogas digestion technology in Africa. Renew. Sustain. Energy Rev. 2017, 67, 1162-1179. [CrossRef]

76. Ali, G.; Nitivattananon, V.; Abbas, S.; Sabir, M. Green waste to biogas: Renewable energy possibilities for Thailands green markets. Renew. Sustain. Energy Rev. 2012, 16, 5423-5429. [CrossRef]

77. De Clercq, D.; Wen, Z.; Gottfried, O.; Schmidt, F.; Fei, F. A review of global strategies promoting the conversion of food waste to bioenergy via anaerobic digestion. Renew. Sustain. Energy Rev. 2017, 79, 204-221. [CrossRef]

78. Surendra, K.C.; Takara, D.; Hashimoto, A.G.; Khanal, S.K. Biogas as a sustainable energy source for developing countries: Opportunities and challenges. Renew. Sustain. Energy Rev. 2014, 31, 846-859. [CrossRef]

79. Indurkar, M.; Pallath, D.; Chandel, K. Assessment of Municipal Solid Waste Based Biogas Plants in India. In Proceedings of the 3RINCS, Bangkok, Thailand, 2019; Available online: http://www.technobiz.org/3R-2019-Abstracts/Session-6-Biological\%20treatment\%20of\%20MSW/ 6-4\%20Munish\%20Kumar\%20Chandel-oral2\%20.pdf (accessed on 4 September 2019).

80. Pandyaswargo, A.H.; Onoda, H.; Nagata, K. Energy recovery potential and life cycle impact assessment of municipal solid waste management technologies in Asian countries using ELP model. Int. J. Energy Environ. Eng. 2012, 3, 28. [CrossRef]

81. Chen, Y.; Cheng, J.J.; Creamer, K.S. Inhibition of anaerobic digestion process: A review. Bioresour. Technol. 2008, 99, 4044-4064. [CrossRef] [PubMed]

82. $\mathrm{Mu}, \mathrm{H}$.; Chen, Y. Long-term effect of $\mathrm{ZnO}$ nanoparticles on waste activated sludge anaerobic digestion. Water Res. 2011, 45, 5612-5620. [CrossRef] [PubMed]

83. Mu, H.; Zheng, X.; Chen, Y.; Chen, H.; Liu, K. Response of anaerobic granular sludge to a shock load of zinc oxide nanoparticles during biological wastewater treatment. Environ. Sci. Technol. 2012, 46, 5997-6003. [CrossRef] [PubMed]

84. Altaş, L. Inhibitory effect of heavy metals on methane-producing anaerobic granular sludge. J. Hazard. Mater. 2009, 162, 1551-1556. [CrossRef] [PubMed]

85. Aquino, S.F.; Stuckey, D.C. Bioavailability and toxicity of metal nutrients during anaerobic digestion. J. Environ. Eng. 2007, 133, 28-35. [CrossRef]

86. Bagley, D.M.; Lalonde, M.; Kaseros, V.; Stasiuk, K.E.; Sleep, B.E. Acclimation of anaerobic systems to biodegrade tetrachloroethene in the presence of carbon tetrachloride and chloroform. Water Res. 2000, 34, 171-178. [CrossRef]

87. Risberg, K.; Cederlund, H.; Pell, M.; Arthurson, V.; Schnürer, A. Comparative characterization of digestate versus pig slurry and cow manure-Chemical composition and effects on soil microbial activity. Waste Manag. 2017, 61, 529-538. [CrossRef] [PubMed]

88. Plana, P.V.; Noche, B. A review of the current digestate distribution models: Storage and transport. WIT Trans. Ecol. Environ. 2016, 202, 345-357.

89. Tampere, M.; Viiralt, R. The efficiency of biogas digestate on grassland compared to mineral fertilizer and cattle slurry. Res. Rural Dev. 2014, 1, 89-94.

90. Bhattacharyya, S.C. Energy access programmes and sustainable development: A critical review and analysis. Energy Sustain. Dev. 2012, 16, 260-271. [CrossRef]

91. Kumar, A.; Kumar, K.; Kaushik, N.; Sharma, S.; Mishra, S. Renewable energy in India: Current status and future potentials. Renew. Sustain. Energy Rev. 2010, 14, 2434-2442. [CrossRef]

92. Britz, W.; Delzeit, R. The impact of German biogas production on European and global agricultural markets, land use and the environment. Energy Policy 2013, 62, 1268-1275. [CrossRef]

93. Hettiarachchi, H.; Meegoda, J.; Ryu, S. Organic Waste Buyback as a Viable Method to Enhance Sustainable Municipal Solid Waste Management in Developing Countries. Int. J. Environ. Res. Public Health 2018, 15, 2483. [CrossRef] [PubMed]

94. Uusitalo, V.; Soukka, R.; Horttanainen, M.; Niskanen, A.; Havukainen, J. Economics and greenhouse gas balance of biogas use systems in the Finnish transportation sector. Renew. Energy 2013, 51, 132-140. [CrossRef]

95. Clarke, W.P. The uptake of anaerobic digestion for the organic fraction of municipal solid waste-Push versus pull factors. Bioresour. Technol. 2018, 249, 1040-1043. [CrossRef] [PubMed] 
96. Anyaoku, C.C.; Baroutian, S. Decentralized anaerobic digestion systems for increased utilization of biogas from municipal solid waste. Renew. Sustain. Energy Rev. 2018, 90, 982-991. [CrossRef]

97. Castro, L.; Escalante, H.; Jaimes-Estévez, J.; Díaz, L.J.; Vecino, K.; Rojas, G.; Mantilla, L. Low cost digester monitoring under realistic conditions: Rural use of biogas and digestate quality. Bioresour. Technol. 2017, 239, 311-317. [CrossRef] [PubMed]

98. Dahlin, J.; Herbes, C.; Nelles, M. Biogas digestate marketing: Qualitative insights into the supply side. Resour. Conserv. Recycl. 2015, 104, 152-161. [CrossRef]

99. Tsachidou, B.; Scheuren, M.; Gennen, J.; Debbaut, V.; Toussaint, B.; Hissler, C.; George, I.; Delfosse, P. Biogas residues in substitution for chemical fertilizers: A comparative study on a grassland in the Walloon Region. Sci. Total Environ. 2019, 666, 212-225. [CrossRef] [PubMed]

100. Breitenmoser, L.; Gross, T.; Huesch, R.; Rau, J.; Dhar, H.; Kumar, S.; Hugi, C.; Wintgens, T. Anaerobic digestion of biowastes in India: Opportunities, challenges and research needs. J. Environ. Manag. 2019, 236, 396-412. [CrossRef] [PubMed]

101. Moreno, V.C.; Papasidero, S.; Scarponi, G.E.; Guglielmi, D.; Cozzani, V. Analysis of accidents in biogas production and upgrading. Renew. Energy 2016, 96, 1127-1134. [CrossRef]

102. Lüker-Jans, N.; Simmering, D.; Otte, A. The impact of biogas plants on regional dynamics of permanent grassland and maize area-The example of Hesse, Germany (2005-2010). Agric. Ecosyst. Environ. 2017, 241, 24-38. [CrossRef]

103. De Clercq, D.; Wen, Z.; Fan, F. Performance evaluation of restaurant food waste and biowaste to biogas pilot projects in China and implications for national policy. J. Environ. Manag. 2017, 189, 115-124. [CrossRef] [PubMed]

104. Heavy Metals and Organic Compounds from Wastes Used as Organic Fertilisers; WPA-Consulting Engineers Inc.: Perchtoldsdorf, Austria, 2004.

105. Liu, C.; Kazunobu, O.; Premakumara, D.G.J. To Resource Management, and Town Development: The Case of Oki Town; IGES \& UNEP: Hayama, Japan, 2018.

106. Bioenergy Process Flow Bio Energy. 2016. Available online: http://www.bio-energy.co.jp/flow/ (accessed on 4 September 2019).

107. BIRU Teknologi BIRU—Rumah Energi. 2015. Available online: http://www.biru.or.id/index.php/digester/ (accessed on 4 September 2019).

108. Biogas Digest Volume II-Aplication and Production Development; ISAT/GTZ: Eschborn, Germany, 1999. 